FIU Law Review

Fall 2007

\title{
“Leave Them Kids Alone” A Proposed Fair Use Defense For Noncommercial P2P Sharing of Copyrighted Music Files
}

Jeremy Scott

Follow this and additional works at: https://ecollections.law.fiu.edu/lawreview

Part of the Other Law Commons

Online ISSN: 2643-7759

\section{Recommended Citation}

Jeremy Scott, "Leave Them Kids Alone" A Proposed Fair Use Defense For Noncommercial P2P Sharing of Copyrighted Music Files, 3 FIU L. Rev. 235 (2007).

DOI: https://dx.doi.org/10.25148/lawrev.3.1.12

This Symposium is brought to you for free and open access by eCollections. It has been accepted for inclusion in FIU Law Review by an authorized editor of eCollections. For more information, please contact lisdavis@fiu.edu. 


\title{
"Leave Them Kids Alone" A Proposed Fair Use Defense For Noncommercial P2P Sharing of Copyrighted Music Files
}

\author{
Jeremy Scott*
}

\section{INTRODUCTION}

Technology is, at once, the "alpha" and "omega" of copyright law. The "alpha" of copyright law was a single invention, " the printing press, which spawned a publishing industry that required government protection from acts of commercial piracy. ${ }^{3}$ The "omega" has come, at various times, in a series of paradigm shifts brought about by new technologies. ${ }^{4}$ These breakthroughs have often forced our legal system to revisit outdated rules that were unable to embrace the benefits of these new technologies in the marketplace. ${ }^{5}$ In fact, we are currently in the midst of such a paradigm shift, and online file sharing is set to become the "omega" of a copyright holder's control over noncommercial sharing of his expressive works.

* J.D., 2007, Florida International University College of Law. I would like to thank Professor Hannibal Travis for guiding me, ever so patiently, through the ins and outs of copyright law and the fair use doctrine, and Eddie Rodriguez, for his helpful, knowledgeable and practical suggestions regarding the best way to go about doing this project. I would also like to extend my thanks to all of the other members of the FIU Law Review for their patience, support and encouragement.

1 Roger Waters, Another Brick in the Wall, Pt. 2, on THE WALL (Sony 1987).

2 There are historical precursors to what we now know as copyright law, but the time required to hand-copy books before the invention of the printing press served as a substantial barrier to commercial piracy. See Craig W. Dallon, The Problem With Congress and Copyright Law: Forgetting the Past and Ignoring the Public Interest, 44 SANTA CLARA L. REV. 365, 377-78 (2004). See also discussion infra Part III(a)(i).

Sony Corp. of America v. Universal City Studios, Inc., 464 U.S. 417, 429-31 (1984).

4 See id. at 430 n.11 (noting Congressional responses in copyright law to new technologies).

5 See, e.g., White-Smith Music v. Apollo, 209 U.S. 1, 18 (1908) (noting that "the use of [piano] rolls, in the absence of statutory protection, enables the manufacturers thereof to enjoy the use of musical compositions for which they pay no value[,]" but holding that "such considerations properly address themselves to the legislative, and not to the judicial, branch of the government."); Williams \& Wilkins Co. v. U.S., 487 F.2d 1345, 1359 (Ct. Cl. 1973) (noting that the advent of the photocopying machine brought "grave uncertainty of the coverage of 'copy' in Section 1 of the 1909 [Copyright Act] and [expressing] doubt [as to] whether it relates at all to periodicals."). 
American and English legal history support a vision of copyright law that is grounded in the premise that copyright exists primarily to maximize public benefit: Once a given work is published, it enters the public domain, but the rights given to those members of the public who possess the work are limited in a manner consistent with the public interest of encouraging authors and artists to create new works. ${ }^{6}$ This public interest is the "purpose" of statutory copyright protection, and the "method" chosen to achieve that purpose is a limited statutory monopoly endorsed by the government, which imposes restrictions on the use of expressive works in a manner that maximizes an author's incentive to create further works.

Part II of this article examines the emerging technology of file sharing and its current status under copyright jurisprudence. This Part also dissects a number of previously proposed solutions to the file sharing "problem," and ultimately sets forth the premise that noncommercial file sharing between private individuals should be considered a fair use for three basic reasons: (1) the Copyright Act of 1976 fails to adequately address the nuances of P2P file sharing, and courts should wait for Congress to act, rather than stepping into Congress's shoes and cobbling together a doctrine of their own; (2) there is a substantial public benefit in the broad dissemination of expressive content brought about by $\mathrm{P} 2 \mathrm{P}$ file sharing systems; and (3) while it is questionable whether noncommercial file sharing actually harms the commercial interests of copyright holders, it cannot, specifically in the case of music sharing, be shown to harm the artists' incentive to create. Therefore, when one considers the significant public interest in efficient dissemination of expressive content, the vast superiority of P2P as a mode of dissemination, the fact that the current record industry does not efficiently incentivize the majority of artists, and the constitutional mandate to apply the statutory monopoly in a limited fashion that directly addresses whether it is incentivizing the creation of expressive content, one could rationally conclude that noncommercial file sharing should be allowed.

Part III of the article examines the history of copyright law, and asks whether modern legislative interpretations of the Copyright Clause such as the Copyright Term Extension Act (CTEA), and judi-

6 Dallon, supra note 2, at 368-71. See also PAUl Goldstein, COPYRIGHT's HighwaY: From Gutenberg to THE Celestial Jukebox 135-44 (2003) (comparing the American "public interest" perspective on copyright with the French tradition of granting copyright based on the moral rights of authors).

7 See discussion infra Part III(c).

8 Sonny Bono Copyright Term Extension Act, Pub. L. No. 105-298, 112 Stat. 2827 (1998) [hereinafter "CTEA"]. 
cial doctrines such as the application of "fair use," are consistent with the underlying public interest rationale for copyright. This Part also details the argument that historically, copyright law was designed to protect the commercial interests of publishers, an interest that may no longer be sacrosanct in the digital environment, and explains why artists' interests and the public's interests may be misaligned with the interests of the current generation of copyright holders. If that much is clear, then the ultimate question becomes one of method. Clearly Congress can act to expand or limit the protections afforded copyright holders, but courts need not be complicit in Congress's approach. They also have the authority, under the Constitution and the fair use doctrine, to jettison the surplus protection necessary in a pre-P2P market and realign the monopoly afforded by copyright with the public benefit and the artists' incentive to create expressive works.

Part IV of this article examines the fair use doctrine in detail; first from a theoretical perspective, and second in its application to new technologies. This Part ultimately argues that fair use should be expanded to examine, in the event of a noncommercial use, whether a given copyright restriction advances or curtails the public interest, and can be shown to be a disincentive to creation. This analysis requires balancing the artists' monetary incentive to create new works with the public's interest in the enjoyment of those works, but this section ultimately sets forth that we should approach infringement permissively where there is no direct commercial benefit conferred upon those copying their material.

Applying this rationale to the recording industry, it becomes clear that the artists' incentive to create music, on average, is not harmed significantly by file sharing, because the vast majority of profit from the production and sale of CDs is retained by the record companies," and only a small amount goes to the artists themselves. ${ }^{10}$ But the very nature of the Internet makes the primary historical functions of the record company-the production, marketing and distribution of CDs-unnecessary. Because there is a great public benefit in having both public domain and copyrighted material available on P2P networks, and because the monetary incentives retained by artists from the sale of their records are so small, noncommercial file sharing on these networks should be a fair use.

\footnotetext{
9 See generally Lee Ann Obringer, Howstuffworks - How Music Royalties Work, at http://entertainment.howstuffworks.com/music-royalties.htm (last visited Feb. 7, 2006).

10 Id.
} 


\section{File Sharing:The (INADVERTENT) CELESTIAl (PANDORA's) JUKEBOX}

In 1995, the Information Infrastructure Task Force ("IITF") coined the term, "Celestial Jukebox," theorizing that at some point in the not-too-distant future, advances in communications technology would enable instantaneous access to all manner of on-demand content, including movies, music, games, and anything else a user could want that had been digitized. ${ }^{12}$ At the time, the IITF thought it would be necessary to readdress some of the core concepts of intellectual property law in order to encourage copyright holders to participate in this new medium for dissemination. ${ }^{13}$ According to Assistant Secretary of Commerce and Commissioner of Patents and Trademarks Bruce A. Lehman:

[a]ll the computers, telephones, fax machines, scanners, cameras, keyboards, televisions, monitors, printers, switches, routers, wires, cables, networks and satellites in the world will not create a successful [Celestial Jukebox], if there is no content. What will drive the [Celestial Jukebox] is the content moving through it.

The IITF was absolutely right about the promise of the technologies it was studying. The Internet infrastructure has a fabulous potential to disseminate information on a never-before-seen scale. It is by far the cheapest and fastest distribution mechanism for expressive or informative works the world has ever seen. What the IITF did not count on was the "culture of free" that grew up in this environment, and that has been responsible for the explosive growth and development of the Internet over the last ten years. ${ }^{15}$ The Internet turned out

11 For a discussion of the mandate of and the procedure taken by the IITF in the midnineties, see Cassandra Infeld \& Victoria Smith Ekstrand, The Music Industry and the Legislative Development of the Digital Millennium Copyright Act's Online Service Provider Provision, 10 COMM. L. \& POL'Y. 291, 297-300 (2005).

12 See GOLDSTEIN, supra note 6, at 187 (discussing the impact of the IITF's "white paper" on the future of digital technology and examining the concept of the "Celestial Jukebox"); see also INFORMATION INFRASTRUCTURE TASK FORCE, INTELLECTUAL PROPERTY AND THE NATIONAL INFORMATION INFRASTRUCTURE, THE REPORT OF THE WORKING GROUP ON INTELLECTUAL PROPERTY RIGHTS 222 (1995) available at http://www.uspto.gov/web/offices/com/doc/ipnii/ipnii.pdf (coining the term, "celestial jukebox").

13 See Intellectual Property and the National Information Infrastructure: The Report of the Working Group on Intellectual Property Rights: Hearing on S. 1284 and H.R. 2441 Before the House Committee on the Judiciary, $104^{\text {th }}$ Cong. (1995) (Statement of Bruce A. Lehman, Assistant Sec'y of Commerce and Comm'r of Patents and Trademarks), available at http://www.uspto.gov/web/offices/com/doc/ipnii/nii-hill.html.

$14 I d$. at 6.

15 Jessica Litman, Sharing and Stealing, 27 HASTINGs COMM. \& ENT. L. J. 1, 4 (2004). 
to be a place where content was freely disseminated and shared between individuals, not hoarded by them. ${ }^{16}$ It is a simple quirk of human behavior that was largely unanticipated by the IITF: There was no need for the government to sponsor the provision of content over the Internet in order to create some kind of "Celestial Jukebox," because users would provide the content themselves, but when the users provided that content, they would not care to distinguish between what was copyrighted and what was not.

As a result, Pandora's Box had been opened. As technology improved, providing ever-faster access to ever-broader content, copyright holders sought refuge from the "culture of free" through litigation. The courts, for their part, were ill-equipped to deal fairly with the issue. They were left interpreting a Copyright Act that was too old to address the changes wrought by the Internet, and applying that Act to technologies that were too young to be fully understood. The results of these litigation efforts created a tennis match of law and technology that continues to this day. And nowhere is the futility of attempting to place restrictions on noncommercial sharing between users more evident than in cases dealing with online file sharing.

\section{A. The File Sharing Controversy}

It seems appropriate that a discussion of the copyright ramifications of file sharing should begin by examining the underlying technology. After all, without this technology, infringement of music copyrights over the Internet would be impossible (or improbable), and there would be no need to delve into questions about the nature of noncommercial copyright infringement or whether, sans protection against this infringement, artists would stop making music. ${ }^{18}$ Copyright law is unique in that its development is inevitably and inexorably tied to the conveniences offered by new technologies. ${ }^{19}$ In fact, this

16 See id.

17 See generally id.

18 This is mentioned by the Founding Fathers as the reason for their grant of statutory monopolies, which, in a diffused form, exist in the Copyright Act. Compare U.S. ConsT. art. I, $\S 8$, cl. 8 ("promot[ing] the Progress of ... useful Arts, by securing for limited Times to Authors ... the exclusive Right to their respective Writings ....") (emphasis added), with 17 U.S.C. $\$ 106$ (2000) (establishing that "the owner of copyright has the exclusive rights to ... authorize" reproduction, the preparation of derivative works, distribution, public performance, display, and digital sound transmissions) (emphasis added), and 17 U.S.C. § 107 (2000) (establishing that a "fair use of a copyrighted work ... is not an infringement of copyright").

19 See Williams \& Wilkins Co. v. U.S., 487 F.2d 1345, 1350 (Ct. Cl. 1973) (noting that "the main reason why determination of the question [of whether library photocopying can constitute a fair use] is so difficult is that the text of the Copyright Act of 1909, which governs the case, does not supply, by itself, a clear or satisfactory answer"), aff'd, 420 U.S. 376 (1975); Sony Corp. of America v. Universal City Studios, Inc., 464 U.S. 417, 431 (1984) (noting that "[s]ound policy, as 
entire area of law became necessary largely because of a single technological development - the printing press ${ }^{20}$ - and subsequent innovations have forced it to develop from narrow protections designed to serve the commercial interests of early publishers to the legal jungle we know today. ${ }^{21}$ In this push-pull relationship between law and technology, it is important to understand the technology first, so that we may accurately assess the law.

File sharing, at its most basic, is a "Frankenstein" of other technologies. The most prominent are file transferring, search engines and compressed file architectures like the mp3 file format. ${ }^{22}$ File transferring enables users to send information directly from computer to computer across a network. A user enters some physical information, which his computer transforms into digital information, then sends that information to another computer, via a modem, DSL line or other device, where it is decoded at the other end. ${ }^{23}$ The ability to transfer files between one computer and another is an inherent component of the architecture of the Internet.

The search engine is simply a "software program that searches a database and gathers and reports information that contains or is related to specified terms." ${ }^{24}$ In a nutshell, a user enters terms from his own computer and the search engine "searches" for those terms on a given network. That network can be large enough to include the entire Internet, or it can be very small, accessing only a limited database of materials. Search engine technology is an extremely valuable method of navigating the information available on the Internet. Some of the larger search engines, like Yahoo! and Google, have become part

well as history, supports our consistent deference to Congress when major technological innovations alter the market for copyrighted materials"); Fortnightly Corp. v. United Artists Television, Inc., 392 U.S. 390, 395 (1968) (noting, in a case dealing with new television signal dissemination technology, that "our inquiry [into the meaning of the Copyright Act] cannot be limited to ordinary meaning and legislative history, for this is a statute that was drafted long before the development of the electronic phenomena with which we deal here").

20 Dallon, supra note 2, at 366-67; see generally ELIZABETH L. EISENSTEIN, THE PRINTING REVOLUTION IN EARLY MODERN EUROPE (1983).

21 See LeOnardas Vytautas Gerulaitis, Printing and Publishing in FifteenthCENTURY VENICE 30-43 (1976) (discussing the various privileges afforded to printers by European governments).

22 Modern file sharing programs like Kazaa are larger and have the ability to share a wider variety of files, such as programs and movies, but this does not change the basic design architecture of file sharing programs.

23 See generally Robert Frieden, MSN Encarta - Telecommunications (2005), at http://encarta.msn.com/encyclopedia_761566546_1/Telecommunications.html (last visited Feb. 7, 2006).

24 "Search Engine," The American Heritage Dictionary of the English Language $\left(4^{\text {th }}\right.$ ed. 1995), available at http://www.ask.com/reference/dictionary/ahdict/58678/search+engine (last visited Feb. 7, 2006). 
of our cultural lexicon. ${ }^{25}$ These large-scale search engines are designed to search the World Wide Web for pages matching users' queries, ${ }^{26}$ but the potential uses of search engine technology are not limited to the World Wide Web. In fact, a searchable database can be built any way a designer wishes, provided he has sufficient technical skills.

The second technological innovation, which was not directly responsible for file sharing technology but had a huge impact on its early viability, is the mp3 file format. Music is encoded on CDs in what is called a ".wav" or "wave" format, which consumes a great deal of computer memory ${ }^{27}$ because the format contains a broad spectrum of sounds. Wave files are less suitable for Internet distribution because their "size," the amount of information one would have to transfer over the web, would make download times prohibitively long. The mp3 format uses what is called "perceptual noise shaping," a compression algorithm that "cuts out" aspects of a recording that a human ear cannot hear, resulting in greatly reduced file sizes that are suitable for dissemination on the Internet. ${ }^{28}$ Although modern file sharing networks share many file types other than the mp3, the idea of trading $\mathrm{mp} 3 \mathrm{~s}$, and arguably a lack of industry involvement in early Internet distribution, spurred the evolution of file sharing technology.

All file-sharing technologies share a similar set of underlying characteristics. At their most basic level, they allow end-users to access a "network" of other computers using the same program. ${ }^{29}$ Once this network of computers is accessed, a built-in search engine allows users to send out requests for a particular file and receive a list of other computers that have that particular file available. ${ }^{30}$ Once the list is

25 Google has even achieved "verb" status. To "google" someone means to search for background information about them on the Web using the popular search engine. See "Google," Webster's New Millennium Dictionary of English, Preview Edition (2005), available at http://dictionary.reference.com/search?q=google (last visited Feb. 7, 2006).

26 Both can search for pictures as well, but it is not possible for Google or Yahoo! to search solely for mp3 files.

27 Marshall Brian, Howstuffworks - "How MP3 Files Work" (2005), at http://computer.howstuffworks.com/mp31.htm (noting that "the average [three minute long] song on a CD consumes about 32 million bytes of space," which is "a lot of space for one song, and it's especially large when you consider that over a $56 \mathrm{~K}$ modem, it would take close to two hours to download that one song," and that "[t]he goal of the MP3 format is to compress a CDquality song by a factor of 10 to 14 without noticably [sic] affecting the CD-quality sound.").

28 See id. (noting that "[w]ith MP3, a 32-megabyte (MB) song on a CD compresses down to about $3 \mathrm{MB}$. This lets you download a song in minutes rather than hours, and store hundreds of songs on your computer's hard disk without taking up that much space").

29 See Hillary M. Kowalski, Peer-to-Peer File Sharing and Technological Sabotage Tactics: No Legislation Required, 8 MARQ. INTELL. Prop. L. REV. 297, 299 (2004) (discussing P2P network architectures).

30 See Damien A. Riehl, Peer-to-Peer Distribution Systems: Will Napster, Gnutella, and Freenet Create a Copyright Nirvana or Gehenna?, 27 WM. MiTCHELL L. REV. 1761, 1764-66, 1773- 
compiled, users can click on a file name or an icon, connect to one of the other computers on the network, and download the file to their own computer. ${ }^{31}$ Once the file is downloaded, it is placed in a folder and may be made available to other users performing their own searches. ${ }^{32}$ In this fashion, files are replicated, multiplied, and propagated throughout a given network. ${ }^{33}$ Of course, the network does not discriminate whether a given file is copyrighted or not; in fact, without a layer of "filtering" software, it would be unable to do so. The "choice" of whether to share copyrighted material has been left up to users, and users have overwhelmingly chosen to share.

There are essentially three iterations of file sharing technologies. "Direct" networks are the simplest form of file sharing, and it would probably be inappropriate to even classify them as "P2P" per se. In a "direct network," users log on or simply visit a website connected to a server that contains media files for download. The user then clicks on an icon and downloads or streams the file directly from the website. "Centralized" P2P networks use central servers as a "hub," indexing the names of each file shared by a given computer and disseminating those names to users looking for similar files to download." "Decentralized" P2P networks are the offspring of the legal failings of "centralized" models. In these networks, some computers act as "nodes,"

76 (2001) (discussing Napster [centralized] and Gnutella [decentralized] file sharing architectures); See also Lisa J. Beyer Sims, Mutiny on the Net: Ridding P2P Pirates of their Booty, 52 EMORY L.J.1907, 1910 (2003) (discussing P2P technology).

31 See generally Damien A. Riehl, Peer-to-Peer Distribution Systems, 27 WM. Mitchell L. REV. 1761 (2001).

32 See Universal Music Australia Pty. Ltd. v. Sharman License Holdings Ltd., [2005] F.C.A. $1242, \S 62$ (noting that by default, the Kazaa P2P system "can be the subject of a search result provided to another Kazaa user and a copy of that file can be transferred from the supplying user's My Shared Folder to the searching user's computer" although that option is cancelable by the user).

33 See id.

34 See Metro-Goldwyn-Mayer Studios Inc. v. Grokster, Ltd., 125 S. Ct. 2764, 2772 (2005) (noting that, according to plaintiff's calculations, 90 percent of music available on defendant's FastTrack network was copyrighted); A\&M Records, Inc. v. Napster, Inc., 239 F.3d 1004, 1025 (9th Cir. 2001) (noting "evidence of massive, unauthorized downloading and uploading of plaintiffs' copyrighted works--as many as 10,000 files per second by defendant's own admission").

35 See UMG Recordings, Inc. v. MP3.Com, Inc., 92 F. Supp. 2d 349 (S.D.N.Y. 2000) (describing the "direct network" technology offered to users by MP3.com).

36 Felix Oberholzer \& Koleman Strumpf, The Effect of File Sharing on Record Sales: An Empirical Analysis 6 (2004), available at http://www.unc.edu/ cigar/papers/FileSharing_March2004.pdf [hereinafter "Oberholzer \& Strumpf Report"]. Oberholzer and Strumpf also discuss a third type of network called a "hybrid" network, but the distinction between "hybrid" and "decentralized is not substantial enough, on a legal level, to warrant discussion here. Id. 
and connect on their own to other computers in the network without accessing any centralized "hub.",

UMG Recordings, Inc. v. MP3.com, Inc. ${ }^{38}$ is a precursor to many of the modern P2P network cases. The defendant, MP3.com, owned a website which contained "tens of thousands of popular CDs in which plaintiffs held the copyrights." ${ }^{39}$ Ironically, MP3.com, unlike later file sharing programs, took steps to prevent unauthorized access to copyrighted music files.

[I]n order to first access [the copyrighted recordings], a subscriber to MP3.com must either "prove" that he already owns the $\mathrm{CD}$ version of the recording by inserting his copy of the commercial CD into his computer CD-Rom drive for a few seconds ... or must purchase the $\mathrm{CD}$ from one of defendant's cooperating online retailers....

Because of these modifications, MP3.com felt it could safely assert a defense of fair use, ${ }^{41}$ a traditional harbor for defendants in copyright infringement cases. MP3.com argued that since it took pains to prevent those who did not already own a CD from accessing its music files, its listeners were merely engaging in what it termed "transformative space shifting," moving music from their CDs to their computers by using the MP3.com service. ${ }^{42}$ This underlying use, MP3.com argued, was fair: (1) because it was transformative from one format to another; (2) because it did not allow users to copy CDs which they did not already own; ${ }^{43}$ and (3) because there was, at that time, no other method of receiving MP3 files over the Internet. Therefore, MP3.com was providing an important service which was unavailable anywhere else. The court, however, noting that the "defendant [sought] to attract a sufficiently large subscription base to draw advertising and otherwise make a profit" from its use of the copyrighted material, held that a defense based on the "fair use" of "transformative space shifting" could not stand.

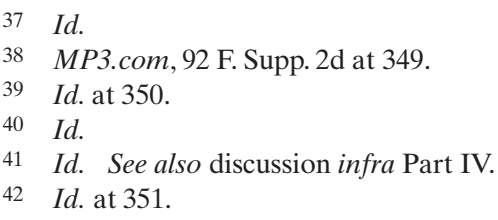

3 Ironically, this space shifting argument was accepted in the context of portable mp3 players. See Recording Industry Ass'n of America, Inc. v. Diamond Multimedia Systems, Inc., 180 F.3d 1072, 1079 (9th Cir. 1999) (affirming the denial of an injunction against a portable MP3 player manufacturer because "the Rio's operation is entirely consistent with the [Home Recording Act of 1992's] main purpose - the facilitation of personal use").

44 MP3.com, 92 F. Supp. $2 \mathrm{~d}$ at 351. 
In $A$ \& $M$ Records, Inc. v. Napster, Inc., the court dealt with its first "true" file-sharing program. Napster was designed and built along a "centralized" model, allowing users to access an index of file listings maintained by a centralized set of servers owned by the defendant. $^{46}$ Napster's servers, unlike MP3.com's, did not contain any copyrighted material at all; they merely indexed lists of files contained on the computers of other Napster users. ${ }^{47}$ The plaintiffs brought suit against Napster for both contributory infringement (knowingly facilitating direct infringement by other users), and vicarious infringement (supervising, controlling, and financially benefiting from the infringement of others). ${ }^{48}$ The court dealt with the issue of whether Napster, because it maintained the indexing servers, had the ability, and therefore the obligation, to prevent infringement on its network. ${ }^{49}$ In response to these allegations, Napster sought refuge, like MP3.com, under the fair use doctrine, setting forth two possible scenarios that should be considered "fair uses" of the Napster system.

The first argument proffered by Napster was that those uploading and downloading files onto its system were "sampling" music in order to decide whether they liked it enough to buy it." Under a sampling rationale, Napster argued, record sales were actually increasing as a result of people having access to the music and being able to listen to it before they bought it. The court ultimately held that this argument was unavailing, making the point that "sampling" affected the hither-

45239 F.3d 1004 (9th Cir. 2001).

46 See id. at 1011-13 (describing the mechanics of Napster's P2P interface); Oberholzer \& Strumpf Report, supra note 37, at 6-7.

47 See Napster, 239 F.3d at 1012 (noting that "the Napster server software obtains the Internet address of the requesting user and the Internet address of the 'host user' (the user with the available files)," that the server then "communicate[s] the host user's Internet address to the requesting user.," and that the "requesting user's computer uses this information to establish a connection with the host user and downloads a copy of the contents of the MP3 file from one computer to the other over the Internet, "peer-to-peer."') (citations omitted).

48 Id. at 1019-22 (discussing Napster's liability for contributory infringement); id. at 102224 (discussing Napster's liability for vicarious infringement).

49 See id. at 1021 (reaffirming and applying to Napster a prior holding stating "that if a computer system operator learns of specific infringing material available on his system and fails to purge such material from the system, the operator knows of and contributes to direct infringement.").

$50 \quad$ Id. at $1017-19$.

51 Id. at 1018.

52 Id. Both the district and appellate courts rejected Napster's proffered evidence of increased record sales as a result of sampling, stating that evidence of "increased sales of copyrighted material attributable to unauthorized use should not deprive the copyright holder of the right to license the material." $I d$. 
to-untapped downloading market negatively, and reasoned that the more "samples" were downloaded, the less music would be sold."

The second argument raised by Napster was that many of the individuals were merely grabbing digital copies of music that they already owned on $\mathrm{CD}$ in order to listen to that music on their computers. ${ }^{54}$ This "space shifting" rationale was also rejected by the court because users did not merely copy CDs they owned by using Napster, but they potentially made those CDs available to millions of people." It was this availability that undermined the persuasiveness of the "space shifting" argument, although it did not undermine the idea of "space shifting" in and of itself.

Napster relied upon a central server to process and store requests by users, so it was comparatively easy for the court to decide that the company had constructive notice of infringing acts committed by users of its network. In re Aimster Copyright Litigation, ${ }^{57}$ on the other hand, presented a different scenario, and seems to have changed the balance of what constitutes infringement. In Aimster, the court held that the defendant was subject to contributory liability for infringing acts by those on its network in spite of the fact that it had no actual knowledge of such acts. ${ }^{58}$ The court's reasoning suggested that the defendant had willfully attempted to blind itself by designing its program in a manner that prevented its distributor from examining the activities of individual users. ${ }^{59}$ In his holding, Judge Richard Posner also noted that:

It is not enough, as we have said, that a product or service be physically capable ... of a noninfringing use. Aimster has failed to produce any evidence that its service has ever been used for a noninfringing use .... ${ }^{60}$

53 Id. This holding was made first by the district court and affirmed by the Ninth Circuit. See A \& M Records, Inc. v. Napster, Inc., 114 F.Supp.2d 896, 914 (N.D. Cal. 2000).

54 Napster, 239 F.3d at 1019.

55 See id. (pointing out that "it is obvious that once a user lists a copy of music he already owns on the Napster system in order to access the music from another location, the song becomes "available to millions of other individuals," not just the original CD owner.").

56 Id. But see Recording Ass'n of Am. v. Diamond Multimedia Sys. Inc., 180 F.3d 1072, 1079 (9th Cir. 1999) (allowing a fair use defense based on space shifting where the plaintiff demonstrated that defendant's product allowed people to rip tracks from their CDs in order to put them on the defendant's mp3 player).

57334 F.3d 643 (7th Cir. 2003).

58 See id. at 650-51 (holding that "that a service provider that would otherwise be a contributory infringer does not obtain immunity by using encryption to shield itself from actual knowledge of the unlawful purposes for which the service is being used.").

59 Id. at 653 (surmising that "Aimster blinded itself in the hope that by doing so it might [avoid liability]").

60 Id. 
Thus, the burden seems to have been shifted to the producer of a product in order to determine whether a user has engaged in a substantial noninfringing use. Under the court's holding in Aimster, it would seem that if actual infringing uses significantly outweigh actual non-infringing uses, a product's producer would be liable whether it intended for those uses to occur or not. ${ }^{61}$ This seems to contravene the standard set forth by the United States Supreme Court in Sony Corp. of Am. v. Universal City Studios, Inc., ${ }^{62}$ which stated that in order to defeat secondary liability, a product need only be capable of a "substantial noninfringing use."

The standard set forth in Sony should have made MetroGoldwyn-Mayer Studios Inc. v. Grokster, Ltd. ${ }^{64}$ a foregone conclusion. The technology in that case was different than the technologies in both Napster and Aimster; and the defendants maintained no control at all over the end-user's use of its product once it reached the market. ${ }^{65}$ The network developed by Grokster was a completely "decentralized" model that consisted solely of end-users' computers. "Unlike the defendant in Napster, Grokster did not have any control, and was therefore not participating in infringement in the sense contemplated by vicarious or contributory liability. ${ }^{67}$ Furthermore, it would have been impossible, under the theory preferred in Aimster, to find that Grokster had constructive notice of actual infringement using its product because Grokster did not participate in any way in the use of the product after it was downloaded from the company's website. ${ }^{68}$ In a nutshell, Grokster had created a product that had characteristics

61 Judge Posner also noted that the tutorials for the defendant's product used nothing but copyrighted music as examples of what could be uploaded and downloaded, which seems to leave open the possibility, which is later explored by the United States Supreme Court in MetroGoldwyn-Mayer Studios Inc. v. Grokster, Ltd., 125 S. Ct. 2764, 2768 (2005), that the manner in which a given product is advertised can have a significant impact on the court's legal view of the purpose and possible uses of the product. See Aimster, 334 F.3d at 652.

62464 U.S. 417 (1984).

63 Id. at 789.

64125 S. Ct. 2764.

65 See id. at 2772 (noting that "Grokster and StreamCast do not [] know when particular files are copied").

66 See id. at 2771; Oberholzer \& Strumpf Report, supra note 36, at 6.

67 Compare Grokster, 125 S. Ct. at 2774-75 (discussing the district and appellate court analyses of the standards for contributory and vicarious liability and their impact on Grokster's secondary liability) with A\&M Records, Inc. v. Napster, Inc., 239 F.3d 1004, 1019-24 (9th Cir. 2001) (applying the established standards of contributory and vicarious infringement to Napster).

68 Compare Grokster, 125 S. Ct. at $2774-75$ (conceding that it would be impossible for Grokster to have knowledge of specific acts of infringement on its network) with In re Aimster Copyright Litigation, 334 F.3d 643, 646 (7th Cir. 2003) (noting that "Aimster's server . . collects and organizes information obtained from the users," making it possible, but for Aimster's "willful blindness," that it could have policed its own servers). 
legally similar to videocassette recorders, which Sony had long ago held to be legal. ${ }^{69}$ Grokster's arguments, in fact, sounded nearly identical to those made by the plaintiffs in Sony and were clearly dependent on the protection offered under that standard. ${ }^{70}$ Grokster set out to prove that at least a small portion of the music and media traded by its users was in the public domain, so the act of uploading and downloading this music was a substantial noninfringing use that should have saved it from liability altogether.

The Supreme Court, however, was not content to allow Grokster to escape liability under the Sony standard. The Court imported a new standard of liability from patent law in order to find Grokster liable. " Under the standard of "inducement" liability, a company or individual could be liable for the infringement of those who use its product if it could be shown that the company marketed the product with the object to promote the copyright infringement of others. ${ }^{7^{3}}$ The court brought up numerous examples showing that Grokster had fashioned itself as "the new Napster," encouraging former Napster users to switch to its service, and that it had sold advertisements on its product with the understanding that it would be a draw to infringing users. $^{74}$ Thus, Grokster effectively engaged in a commercial use by

69 The similarity lies in the fact that, like Sony, Grokster did not have any control over what the end users actually did with its product. It is one thing to say that those who have the ability to prevent infringement have an obligation to do so, which would be the case with the Napster and Aimster services, but like Sony, the only way for Grokster to control infringement was to simply not distribute its $\mathrm{P} 2 \mathrm{P}$ client at all.

70 In Grokster, the United States Supreme Court accuses lower courts of "misunderstanding" the standard for "substantial noninfringing uses" set forth in Sony. Compare Sony Corp. of America v. Universal City Studios, Inc., 464 U.S. 417, 442 (1984) (holding that to escape contributory liability, "a product need merely be capable of substantial noninfringing uses"), with Grokster, 125 S. Ct. at 2774-75, 2778-79 (discussing how, by finding that Grokster was capable of a "substantial noninfringing use," the Ninth Circuit "misapplied" the Court's holding in Sony). It seems rather brusque of the Court to apply a hitherto-unknown standard of "inducement" liability in Grokster and to criticize the lower courts for applying what, at the time, was the only existing precedent. See id. at 2770 (holding, for the first time, "that one who distributes a device with the object of promoting its use to infringe copyright, as shown by clear expression or other affirmative steps taken to foster infringement, is liable for the resulting acts of infringement by third parties").

71 See Grokster, 125 S. Ct. at 2785-86 (discussing the defendant's "substantial noninfringing use" argument).

72 Id. at 2779-80 (characterizing patent law's "inducement rule [as] a sensible one for copyright ....").

73 Id. at 2779.

74 This evidence of the defendant's efforts to promote infringement included:

[i]nternal company documents indicat[ing] that StreamCast hoped to attract large numbers of former Napster users if that company was shut down by court order or otherwise, and that StreamCast planned to be the next Napster[; a] kit developed by StreamCast to be delivered to advertisers [which] contained press articles about 
making a "market" out of copyright infringement that it knew would occur under its network.

An important theme in the line of cases above is commercial benefit. In each case, the defendants derived some kind of commercial benefit from copying by users. It is important to make a distinction here- $\mathrm{P} 2 \mathrm{P}$ users may not be deriving a direct commercial benefit from downloading songs. They are, at most, deriving an indirect benefit by not having to buy CDs, and since people might download music for free that they never would buy anyway, even that is arguably not the case. $^{76}$ The defendants, on the other hand, are all using the users' behavior to make money. MP3.com used its library of copyrighted music to sell advertisements on its website and point users towards sales of CDs through its service; Napster, before its demise as a free-to-use file sharing service, had received over $\$ 85$ million in business loans based on its technology; Aimster "enable[d] the member for a fee of $\$ 4.95 \mathrm{a}$ month to download with a single click the music most often shared by Aimster users"; 78 and Grokster sold a "potential market" of music downloaders to its own advertisers. ${ }^{79}$ The Supreme Court's Sony doctrine has not been applied yet to relieve P2P distributors of liability. And it is arguably the inherent commerciality in each of these cases that is a sticking point for the courts.

What can the preceding cases tell us about the current legality of file sharing software? With respect to Internet file sharing, courts seem to be playing a cat-and-mouse game with technology innovators.

StreamCast's potential to capture former Napster users[;] and [evidence showing that] it introduced itself to some potential advertisers as a company "which is similar to what Napster was," . . . . [In addition, StreamCast] broadcast banner advertisements to users of other Napster-compatible software, urging them to adopt its OpenNap. ... An internal e-mail from a company executive stated: "We have put this network in place so that when Napster pulls the plug on their free service ... or if the Court orders them shut down prior to that ... we will be positioned to capture the flood of their 32 million users that will be actively looking for an alternative.

Id. at 2773 (citations omitted).

75 Id.

76 This is the crux of the "sampling" argument made by Napster. See Napster, 239 F.3d at 1018-19 (discussing Napster's "sampling” fair use defense).

77 Brad King, Wired News: Last Rites for Napster (2002), at http://www.wired.com/news/busi-ness/0,1367,52532,00.html (last visited Mar. 8, 2006).

78 In re Aimster Copyright Litigation, 334 F.3d 643, 652 (7th Cir. 2003).

79 Grokster, 125 S. Ct. at 2773.

80 On the other hand, Sony's commercial relationship to user infringement was more protracted than any of the online file sharing services. As the Court noted, "private, noncommercial time-shifting in the home[,]" the most statistically significant use of VTRs, "plainly satisfies" the substantial noninfringing use standard. Sony Corp. of America v. Universal City Studios, Inc., 464 U.S. 417, 442 (1984). The court also noted that "primary use of the machine" for most owners was this noninfringing time-shifting. $I d$. at 423. 
A new invention comes along; users use the invention to infringe; copyright holders, unwilling to file suit against the users, file a suit against the makers of the new technology under some kind of satellite doctrine, such as contributory, vicarious or inducement liability; the courts find a way, either by adopting existing precedent or importing new concepts of liability, to hold the technology maker liable; and the technology companies go back to the drawing board and create a new invention that meets the qualifications set forth in the courts' latest precedent. The cycle could be endless, and the international nature of the Internet makes the cost of enforcing these copyrights on a collective scale prohibitive and unwieldy. Because everyone in the world is connected, and because a number of governments in the world have different concepts of copyright, ${ }^{82}$ it may be impossible to ever fully (or even reasonably) regulate copyrights over the Internet. How does one preserve music copyright in a file-sharing environment? And if we cannot stop people from sharing copyrighted material, in the words of Professor Litman, how do copyright holders "compete with free" ${ }^{83}$ Is file sharing litigation essentially quixotic?

\section{B. Proposed File Sharing Solutions}

A number of solutions to file sharing liability have already been proposed to balance out the interests of the parties involved and promote broader access to materials. They all have their faults, but they are a good starting point for this discussion. The solutions proposed so far can be broken down into two basic categories: those focused on maintaining the status quo and those focused on imposing a levy or

81 The RIAA does file suits against individuals infringing on file-sharing networks. Obviously, however, the volume of suits is nowhere near the volume of users sharing copyrighted material. See generally Nick Mamatas, Meet John Doe: The RIAA Runs Its Lawsuits as a Volume Business, and Sometimes Downloaders Just Gotta Settle, Village VoICE, Mar. 7, 2005, at 34, available at http://www.villagevoice.com/music/0510,mamatas,61813,22.html (last visited Mar. 8, 2006).

82 The European Union has a very different view of copyright, which is predicated on "natural law." GOLDSTEIN, supra note 6, at 135-61 (discussing the philosophical and practical differences between European and American visions of copyright law). "The natural law or property right theory supports a different balancing of interests than does the [American] theory and supports very long - even perpetual - copyright terms." Dallon, supra note 2, at 443-44. Professor Lawrence Lessig suggests that the divergence in our modern understandings of copyright law could, in an historical sense, be the result of the difference between viewing copyright as a "property" right (which would seem to imply very broad "natural law" protection) and a "monopoly" right (which would seem to imply "public interest" limitations on protection). See LAWrence Lessig, Free Culture - How Big Media Uses Technology and the LaW to LOCK DOWn Culture AND CONTROL CREATIVITY 88 (2004).

83 Litman, supra note 15 , at 35. 
tax and distributing the proceeds based on how an expressive work performs in the marketplace, be that marketplace digital or analog. ${ }^{8 .}$

Many of the problems with maintaining the status quo should be evident at this point. The copyright statute has simple terms for enforcement. In order to prove copyright infringement, one needs only prove that a defendant (1) had access to the materials and (2) copied them. ${ }^{85} \quad$ But the provisions of the copyright statute itself and the statements of the members of Congress involved in enacting it seem to suggest, at least in passing, that the statute was principally designed to prevent commercial infringement. ${ }^{86}$ When someone is making copies and selling them, the infringement is clear, but what happens when one has the ability to create a potentially infinite number of perfect copies of a given piece of music and wants no remuneration in return for their distribution? As noted by Professor Litman:

Under our current system, immensely talented and hard working composers and musicians, who create great stuff that people would want to buy if they knew about it, are often unable to make a living making music, because the system we rely on to encourage the creation and dissemination of music works best when its products are scarce. As a necessary corollary of a distribution mechanism that requires significant investment of capital in order to deliver music to consumers, that fact may be a regrettable but a reasonable sacrifice at the altar of great music. Extending the lotterylike nature of today's conventional music market to a digital world, though, where maintaining scarcity is more expensive than tolerating ubiquity, is profoundly dysfunctional.

To put this point succinctly, a copyright statute that protects against noncommercial distribution of music makes sense when one is trying to encourage the creation and publishing of a given piece of media, but not when there are no publishing or distribution costs to contend with. lars).

84 See id. at 32-34 (discussing various solutions to P2P file sharing proposed by legal scho-

85 See e.g., Playboy Enterprises, Inc. v. Frena, 839 F. Supp. 1552 (M.D. Fla. 1993) (noting that infringement "may be inferentially proven by showing that Defendant ... had access to the allegedly infringed work ... and that one of the rights statutorily guaranteed to copyright owners is implicated by [his] actions.”); see 17 U.S.C. $§ 106, \S 504$ (2000).

86 See discussion infra Part III(b); see generally H.R. REP NO. 94-1476 (1976) (laying out Congress's understanding of the 1976 Copyright Act).

87 Litman, supra note 15 , at 35.

88 See discussion infra Part III(c). 
Under the old model, Congress was given a Constitutional mandate to "promote the progress of science and the useful arts" by granting a statutory copyright monopoly. "Promoting progress," in the context of copyright, mandates that Congress employ its power to grant limited statutory monopolies in a manner that encourages creation and dissemination..$^{90}$ An artist is encouraged to create works, under the copyright clause, because if he creates something someone else wants to buy, the artist will be able to make money from it, and the law enforces his right to be the only person to do so. The only way the artist can reap the benefits of the clause, however, is by disseminating his work. It is important to realize that in the days before digital technology, the prospect or recording, marketing and distributing a work for sale throughout the United States was daunting. ${ }^{91}$ Artists would rarely have had the means to do this on their own, therefore publishing companies were introduced into the mix. ${ }^{92}$ It was not only necessary for the law to protect the artist's remuneration, but it also had to offer enough of a benefit that the artist would have something to offer a publisher in order to encourage dissemination. In this way, the "old" copyright law protects publishers interests and artist's interests together.

In a digital model, the additional remuneration the law formerly offered to encourage publishing is no longer necessary. Publishing a work on the Internet is now as easy as placing the file in a shared folder on one's hard drive. Effectively, the "marginal costs" associated with music dissemination have disappeared." The only costs left are the "fixed costs" of creation. ${ }^{94}$ Because artists, under the current sys-

89 U.S. CONST. art. I, $\S 8$, cl. 8.

90 Litman, supra note 15, at 2; see generally Stephen Breyer, The Uneasy Case for Copyright: A Study of Copyright in Books, Photocopies and Computer Programs, 84 HARV. L. REV. 281 (1970).

91 Litman, supra note 15 , at 2.

92 Id.

93 A marginal cost is:

The additional cost needed to produce or purchase one more unit[s] of a good or service. For example, if a firm can produce 150 units of a product at a total cost of $\$ 5,000$ and 151 units for $\$ 5,100$, the marginal cost of the 151 st unit is $\$ 100$.

David L. Scott, Marginal Cost, WALL STREET WORDS: AN A TO Z GUIDE TO INVESTMENT TERMS FOR TODAY'S INVESTOR (2003), available at http://dictionary.reference.com/search?q=marginal\%20cost (last visited Mar. 16, 2006).

94 A fixed cost is:

[a] cost that remains unchanged even with variations in output. An airline with 20 airplanes has the fixed costs of depreciation and interest (if the planes are partially financed with debt), regardless of the number of times the planes fly or the number 
tem, are rarely able to turn a profit off of the dissemination of their recorded works, it seems implausible to suggest that the possibility of financial gain from one's recorded music serves as an incentive to creation.

A number of scholars have suggested that Congress deal with the file-sharing dilemma by imposing taxes or levies on all kinds of different products and services. This levy or tax would then be divided according to a given formula and distributed to copyright holders. Professor Neil Netanel ${ }^{96}$ suggests a "noncommercial use levy," a fee imposed on products and services whose value is enhanced by P2P file sharing, which could include iPods and other MP3-related devices, blank CDs, computers, Internet access, and any number of other products. ${ }^{97}$ Professor Glynn Lunney ${ }^{98}$ concurs with Professor Netanel, but would limit his levy to "equipment and blank storage media that enable .. copying." Professor Lawrence Lessig has proposed solutions that involve registration of copyrighted works and unique copyright ID tags that could be used to redistribute the income generated by a tax on digital recording services, digital storage media and Internet access services. ${ }^{100}$ The Electronic Frontier Foundation ("EFF") has offered its own solution-music companies offer fans a license to share for a monthly fee.

of seats filled on each flight. Firms with high fixed costs tend to engage in price wars and cutthroat competition because extra revenues incur little extra expense. These firms tend to experience wide swings in profits.

David L. Scott, Fixed Cost, WALL STREET Words: AN A to Z GUIDE TO INVESTMENT TERMS FOR TODAY'S INVESTOR (2003), available at http://dictionary.reference.com/search?q=marginal\%20cost (last visited Mar. 16, 2006).

95 Litman, supra note 15, at 31-32. Unfortunately, artists rarely turn a profit from their recorded works. Singer Janis Ian posits that "everyone is forgetting the main way an artist becomes successful - exposure. Without exposure, no one comes to shows, no one buys CDs, no one enables you to earn a living doing what you love." Janis Ian, The Internet Debacle - An Alternative View, PERFORMING SONGWRITER MAG., Jun. 2002, available at http://www.janisian.com/article-internet_debacle.html [hereinafter "Ian Article"].

96 Neil Netanel is currently a professor at U.C.L.A. His biography is available at http://www.law.ucla.edu/home/index.asp?page=637 (last visited Mar. 8, 2006).

97 See Neil W. Netanel, Impose a Noncommercial Use Levy to Allow Free Peer-to-Peer File Sharing, 17 HARV. J. L. \& TECH. 1, 43-44 (2003) (discussing which products should be taxed under a noncommercial use levy).

98 Glynn Lunney is currently a professor at Tulane University, his biography is available at http://www.law.tulane.edu/tuexp/facadmin/biotemplate.cfm?username=glunney\&status=faculty (last visited Mar. 8, 2006).

99 Glynn S. Lunney, Jr., The Death of Copyright: Digital Technology, Private Copying, and the Digital Millennium Copyright Act, 87 VA. L. REV. 813, 852-53 (2001).

100 LESSIG, supra note 82, at 300-04.

101 Electronic Frontier Foundation, A Better Way Forward: Voluntary Collective Licensing of Music File Sharing (Feb. 2004), available at http:// www.eff.org/share/collective_lic_wp.pdf. 
All of these solutions involving taxes and levies suffer from two major shortfalls. First, taxes or levies on goods and services that can be used for file sharing seem inappropriate, because those who purchase those goods or services but do not engage in file sharing, are forced to subsidize those who do. ${ }^{102}$ The second problem with these solutions is the redistribution mechanism. Whenever a tax or levy is involved, someone is going to have to calculate percentages of wealth and redistribute that income to artists. How should it be calculated fairly? What if artists wish to opt out of the system? What if P2P technology designers opt out? Artists and the public would trade the costs of publishing music for the costs of keeping track of it. Such a system, on a scale of millions (or possibly billions) of downloads may become prohibitively expensive.

Perhaps the best solution is to accept the fact that noncommercial $\mathrm{P} 2 \mathrm{P}$ file sharing is here to stay. It is ubiquitous; it is growing, and it is, to a large extent, impossible to regulate. The IITF's "Celestial Jukebox" already exists, but no one is paying for it, and in all likelihood no one ever will. Why are we concerned about denying the public, the beneficiaries of the Copyright Clause, access to the works of artists, the other beneficiaries of the Copyright Clause, when it is self evident that this denial of access does not financially benefit the vast majority of artists and will hamper our best tools for the dissemination of existing works?

In short, maybe it would be best if we just "leave them kids alone."

\section{INFRINGEMENT: PROTECTING THE "MILKMEN OF THE DIGITAL AGE"}

A milkman is a person ... who delivers milk in milk bottles or cartons .... Originally, milk needed to be delivered to houses on a daily basis as poor refrigeration meant it would quickly spoil. The near-ubiquity of refrigerators in homes in the developed world has decreased the need for frequent milk delivery over the past half-century and made the pro-

102 Licensing ideas like the one proposed by the EFF have not gotten a warm reception from industry insiders. RIAA vice president of government relations, David Sutphen, points out two problems in the voluntary licensing scheme: first, users who agree to the licensing scheme wind up subsidizing sharing by users who simply continue to participate in free downloading, and second, the system essentially equalizes the value of all recorded music. Such a system, according to Sutphen, "means that 'Ice Ice Baby' has as much value as the Beatles catalog does." Lindsay Martell, A License to Share: Group Proposes Music Licensing Scheme for Music File Networks, ABCNEwS.COM, March 1, 2004, http://www.g4tv.com/techtvvault/features/47196/A_License_to_Download.html. 
fession shrink in many localities and disappear totally in others. Additionally, milk delivery incurs a small cost on the price of dairy products that is increasingly difficult to justify -...

There was a time when it made sense to have milkmen, they were a spoke in the wheel of a dairy distribution system for which there was no viable alternative. But as refrigeration technology improved, the need for milkmen waned, and once that need disappeared, the occupation soon followed. The parallel of the milkman in our digital age is the record label. At the time of the 1976 Copyright Act, there was no such thing as "online," let alone an "online music distribution mechanism." It seemed logical to focus infringement law, at least with respect to music, or "phonorecords," as they are referred to by the statute, ${ }^{104}$ around a business model which contemplated not only the cost incurred by an artist in creating music but the cost incurred by a publisher in distributing it.

In fact, the more closely one examines the history of copyright law and the doctrine in its modern form, the more one sees that this law, from its earliest roots, was designed to address the commercial interests associated with publishing. What happens, however, when existing copyright law comes into conflict with the "culture of free"? Are the provisions of the 1976 Act adequately written to deal with the realities of online file sharing? Or do the protections given to copyright holders under the 1976 Act really amount to a law that says we have to use milkmen?

\section{A. A Brief History of Copyright}

In order to understand why copyright law is the way that it is and how it could be understood differently in a P2P environment, it is important to get a sense of its history. From the printing press to the VCR, copyright law has always been forced to change in response to

103 Wikipedia, Milkman, http://en.wikipedia.org/wiki/Milkman (last visited Mar. 10, 2006). The original record label-milkman analogy was made by author Matt Bai. Matt Bai, Hating

Hillary, WIRED MAG. (Feb. 2003), available at
http://www.wired.com/wired/archive/11.02/hating_pr.html (last visited Mar.16, 2006).

104 The 1976 Copyright Act states that:

\footnotetext{
'Phonorecords' are material objects in which sounds, other than those accompanying a motion picture or other audiovisual work, are fixed by any method now known or later developed, and from which the sounds can be perceived, reproduced, or otherwise communicated, either directly or with the aid of a machine or device. The term "phonorecords" includes the material object in which the sounds are first fixed.
} 
new methods of creation and dissemination, and throughout the history of copyright law, publishers' interests and artists' interest have been essentially aligned; artists, in order to disseminate their work, needed publishers, and publishers, in order to have work to disseminate, needed artists.

The needs of artists and publishers, however, are not the only needs enshrined in copyright's history; in fact, they are not even the primary needs, the primary beneficiary of copyright law has always been the public interest. Under the old model, the public's interest, artist's interest, and publisher's interest aligned under a model that used copyright terms in order to guarantee a large enough return on a publisher's investment to justify its risk in selecting an artist's material and disseminating it to the public. Under our new model, where the publisher's importance is vastly decreased because self-publishing by artists is cheap and easy, historically sensible incentive schemes may no longer be necessary.

\section{The roots of copyright}

Although the roots of our modern statutory copyright law are English, there are conceptual antecedents dating back much further. ${ }^{10 .}$ Jewish law, for instance, provides one of the first example of law that could be regarded as protecting what we now know as the "public domain," by "endors[ing] and even command[ing] the faithful reproduction of scriptural and other texts." ${ }^{106}$ This was seen as necessary because these texts were a primary source of Jewish law, and the distribution of Jews throughout the world made it necessary to have faithful reproductions in order to disseminate them to the population and preserve them over a long period. ${ }^{107}$ Jewish law demanded two things of those who would copy texts; it required that the texts be copied faithfully, and it required attribution to the original author. ${ }^{108}$

The earliest account of a copyright "case" comes from Ireland. ${ }^{109}$ A monk named Columba ${ }^{110}$ visited his former instructor, Finnian, at a

105 See Dallon, supra note 2, at 369-402 (discussing historical antecedents to English and American copyright law).

106 Id. at 372.

107 Id.; see generally MAX I. DiMONT, JEws, GOD AND HistORY (1962) (discussing Jewish Diaspora and survival over the culture's 4,000-year history).

108 See Dallon, supra note 3, at 372-73.

109 There is no surviving record, but the story is recounted in CHARLES Forbes Montalembert, SAint Columba: Apostle of CALEDONIA 18-21 (1898).

110 "Columba" would later become "Saint Columba," a seminal figure in Irish history and folklore. See generally id; Wikipedia, Saint Columba, http://en.wikipedia.org/wiki/Saint_Columba (last visited Mar. 10, 2006). 
monastery, and secretly copied a psalter. ${ }^{111}$ When Finnian learned of this, he demanded that Columba give him the copy. ${ }^{112}$ Columba refused, and the case was brought before the King. ${ }^{1.3}$ The King sided with Finnian, holding "[t]o every cow her calf, and consequently to every book its copy."114 The King, looking at whether "one in rightful possession of a manuscript ha[d] the right to copy it without permission of the manuscript's owner," answered "No."

In spite of these early antecedents, what really drove the creation of what we now know as copyright law was the invention of the printing press, which broke through the logistical concerns previously presented by copying manuscripts by hand. ${ }^{116}$ Gutenberg developed the first printing press in Mainz, Germany around 1450 and published the first printed book, the Gutenberg Bible, ${ }^{117}$ in 1455 or early $1456 .^{118}$ The printing press allowed the production and dissemination of literature on a never-before seen scale. Thousands who previously were unable to access any sort of literature because the cost involved in handcopying it made it prohibitively expensive could now afford such works.

The printing press also placed economic pressure on a new and powerful class of tradesmen, the publishers. ${ }^{119}$ The prospect of "publishing" a manuscript on any scale was an expensive one because it involved a significant initial outlay for typesetting, raw materials, distribution and other costs associated with manufacturing books. ${ }^{120} \mathrm{~A}$ major concern among publishers was that a second publisher could buy a single copy of an initial publisher's book, use his own press, print a similar copy, and render the initial publisher (and potentially, the second publisher) unable to recoup his investment. ${ }^{121}$ On the other hand, the public benefit incurred by society from the broad dissemina-

111 MONTALEMBERT, supra note 109, at 18. A "psalter" is "a book containing the psalms separately printed or esp[ecially] arranged for liturgical or devotional use . ..." 2 WEBSTER's THIRD NEW INTERNATIONAL DICTIONARY 1829 (1986).

112 Id. at 18 .

113 Id. at $18-19$.

114 Id. at 21.

115 Dallon, supra note 2, at 376.

116 Id. at 378.

117 For an overview of the Gutenberg Bible, which includes background on the invention of the printing press and scans of the actual text of two editions of the original book, see Gutenberg Bible: View the British Library's Digital Versions Online, http://www.bl.uk/treasures/gutenberg/homepage.html (last visited Mar. 10, 2006).

118 See N.F. BLAKE, CAXTON: ENGLAND's First PUBLISHER 4 (1976).

119 See Dallon, supra note 2, at 381 (noting that printers, "[b]y nature of the business, they tended to be educated and well connected.").

120 See id. (noting that printers would need "substantial financial backing to afford the capital investment required to obtain and maintain a printing press and run a business.").

121 Id. at 382. 
tion of these published books was enormous. ${ }^{122}$ Clearly, the printing of books was an interest that was worthy of some kind of legal protection.

It was with both of these concerns in mind that governments soon began to protect the interests of publishers by granting "specific privileges ... to particular publishers for particular works and usually for limited times." put printers in a position where they could safely recoup their investments for a particular work without fear of piracy. ${ }^{124}$ Some licenses also began to be granted to authors, giving them the right to choose which printer would be authorized to print their work. ${ }^{125}$ The "printer's license" was essentially an ad hoc arrangement, which soon began to present problems because over time, the licenses began to conflict with one another. ${ }^{126}$ Governments began moving toward a more comprehensive solution to protecting the interests of authors and the expenses incurred by printers. Statutes became necessary.

\section{Statutory copyright In England}

The modern statutory precursor to our current copyright law is the Statute of Anne, which was enacted by the British Parliament in $1710 .^{127}$ The purpose of the Statute was to promote the encouragement of learning, and the method by which this purpose was achieved was by granting authors limited property rights over the printing of their books. $^{128}$ The failure to grant these limited monopolies, as claimed by

122 This is the genesis of the "public benefit" rationale. Public access to printed works was enabled by mass dissemination, which in turn was enabled by the printing press, which in turn was arguably responsible for the renaissance and the protestant reformation. See generally EISENSTEIN, supra note 20.

123 Dallon, supra note 2, at 383.

124 See id. at 382.

125 See id. at 383-84 (describing an exclusive right granted by Venetian authorities to the author Marcus Antonius Sabellicus to authorize a printing of his history of Venice; this is arguably the first such right granted to an author).

126 The government in Venice:

granted numerous privileges but some were conflicting or ambiguous. One privilege was granted but identified neither the protected title nor author. Other privileges were obtained in bad faith - where the privilege holder had no intention of publishing the work, but rather intended to extract payment for the rights, or simply intended to prevent others from publishing the work.

Id. at 385-86 (footnote omitted).

127 LESSIG, supra note 82 , at 86.

128 The statute's preamble spells out these goals unmistakably. See Statute of Anne, 1710, 8 Ann., c. 18 (Eng.), available at http://www.copyrighthistory.com/anne.html. 
English author Daniel Defoe, ${ }^{129}$ would result in "a Discouragement to Industry, a Dishonour to Learning, and a Cheat upon the whole Nation." ${ }^{130}$ Although the Statute of Anne granted the limited monopoly that Defoe and his contemporaries pleaded for, it did so with significant limitations. The grant of monopoly under the Statute lasted, in the case of new works, for only 14 years. ${ }^{131}$ Another significant limitation was the purpose of the act itself, which is enshrined in its characterization by Parliament as "[a]n act for the encouragement of learning, by vesting the copies of printed books in the authors or purchasers of such copies, during the times therein mentioned." couragement of learning" via the dissemination of works and encouragement of new works was the foremost concern of British Parliament, not necessarily the property rights of the authors.

This distinction played itself out in the case of Donaldson $v$. Beckett, where the King's Bench affirmed that the protections extended to authors under the Statute of Anne subsumed any copyrights which may have existed under common law before the Statute was passed. ${ }^{134}$ Similarly, in Newbery's Case, the court held that an act of abridgment, where the defendant had abridged and published Hawkesworth's novel Voyages, Newbury was not only exculpated from liability for copyright infringement but was congratulated for reducing the size of Hawkesworth's novel and presenting it in a more readable fashion. ${ }^{135}$ This rule condoning "fair abridgment," coupled with the rejection of a common law extension of the statutory monopoly granted to copyright holders, seemed to place the public's interest in getting access to information in front of the author's or publisher's interest in having an exclusive right to his work.

\section{Constitutional copyright in the United States}

The United States Constitution is the basis of our understanding of copyright law. It creates power in Congress to "To promote the Progress of Science and useful Arts, by securing for limited Times to

129 Daniel Defoe is best known to history as the author of Robinson Crusoe. See Wikipedia, Daniel Dafoe, http://en.wikipedia.org/wiki/Daniel_Defoe (last visited Mar.10,2006).

130 Dallon, supra note 2, at 404. Note that this claim seems disingenuous on Defoe's part. It does not appear that the lack of a law like the Statute of Anne discouraged him from becoming an author.

131 Statute of Anne, supra note 128.

132 Id.

133 Id.

134 Donaldson v. Beckett, 98 Eng. Rep. 257 (K.B. 1774); see generally GOLDSTEIN, supra note 6, at 38-40; LESSIG, supra note 82, at 92-94.

135 See Newbery's Case, 98 Eng. Rep. 913 (Ch. 1773); see also John Tehranian, Et Tu, Fair Use? The Triumph of Natural-Law Copyright, 38 U.C. DAVIS L. REV. 465, 479-480 (2005). 
Authors and Inventors the exclusive Right to their respective Writings and Discoveries." ${ }^{136}$ Like the Statute of Anne, the delegates of the Constitutional convention created a law that represented a combination of a "purpose," "to promote the progress of science and the useful arts" and a "method," which is to secure "for limited Times to Authors and Inventors the exclusive Right to their respective Writings and Discoveries." ${ }^{137}$ In The Federalist \#43, James Madison stated that "[t]he utility of this power will scarcely be questioned. The copyright of authors has been solemnly adjudged in Great Britain, to be a right of common law ${ }^{138} \ldots$. The public good fully coincides ... with the claims of individuals." $" 139$

Although this clause was approved unanimously, it actually represents an amalgamation of several clauses proposed by numerous delegates of the Constitutional Convention. ${ }^{140}$ The existing Copyright Clause was originally two clauses. ${ }^{141}$ One vested a power in Congress to "secure literary authors their copy rights for a limited time," and the other vested a power to "encourage ... the advancement of useful knowledge and discoveries," to "grant patents for useful inventions," and to "secure the inventors of useful machines and implement the benefits thereof for a limited time." ${ }^{142}$ These goals, which relate to both copyrights and patents, were all combined for the purposes of Article I, section 8 , clause 8 . $^{14}$

In spite of their votes, many of the Founding Fathers were concerned that the application of the Copyright Clause be balanced in order to achieve the maximum public benefit. Madison shared his concerns about the monopolistic nature of copyright in a letter to Thomas Jefferson, opining that monopolies "are justly classed among the greatest nusances [sic] in Government. But is it clear that as encouragements to literary works and ingenious discoveries, they are not too valuable to be wholly renounced?" ${ }^{14}$ Jefferson, in his letters, ex-

136 U.S. CONST. art. I, $\S 8, \mathrm{cl} .8$.

137 Compare Statute of Anne, supra note 128, with U.S. CONST. Art. I, § 8, cl. 8.

138 Madison is arguably incorrect on this point, as is indicated in Donaldson. See Donaldson, 98 Eng. Rep. at 257 (holding that either (1) a perpetual common law copyright does not exist, or (2) the Statute of Anne superseded whatever common law protection authors had).

139 The Federalist No. 43 (James Madison).

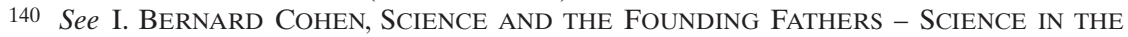
Political Thought of JefFerson, Franklin, AdAMs, AND MADison 239-40 (1995) (detailing the underpinnings of the Copyright Clause and subsequent revisions thereof).

141 Id. at 240 .

142 Id.

143 Id.

1441 THE REPUBLIC OF LETTERS:THE CORRESPONDENCE BETWEEN THOMAS JEFFERSON AND JAMES MADISON 1776-1826, at 566 (James Morton Smith ed., 1995); see also Dallon, supra 
pressed a dim view of the idea that the Constitution should intrinsically support grants of monopoly. ${ }^{145}$ Both, however, seemed to recognize that society could derive a great public benefit from authors and inventors under a proper and balanced application of the Copyright Clause.

Although the "public benefit rationale" was the clear underlying purpose of the Copyright Clause, scholars have proposed an alternate understanding, a "natural law" or "property rights" rationale, ${ }^{146}$ which is more in keeping with old Irish pronouncement of "to every cow her calf, and to every book its copy.", ${ }^{147}$ However, even the most ardent supporters of a "natural law" theory of copyright understood, at the time of the Constitutional Convention and for years beyond, that the Copyright Clause of the Constitution did not support their view of intellectual property rights. Noah Webster, ${ }^{148}$ a staunch supporter of the "natural law" theory of copyright, reluctantly admitted that, since Donaldson, "it seems to have been generally admitted that an author has not a permanent and exclusive right to the publication of his original works at common law." ${ }^{, 49}$

Congress enacted the first copyright statute in 1790, which was entitled "[a]n Act for the encouragement of learning, by securing the copies of maps, charts, and books, to the authors and proprietors of such copies, during the times therein mentioned." tors have suggested that, in spite of the clear language in the title of the Act, Congress merely thought it was giving statutory effect to an existing right. ${ }^{151}$ The Supreme Court, however, specifically rejected this assertion in Wheaton v. Peters, ${ }^{152}$ holding that any property rights of owners possessed to unpublished manuscripts under the common law were extinguished upon publication. ${ }^{153}$ After a manuscript was

note 3, at 424-25 (summarizing the correspondences between Madison and Jefferson involving copyright).

145 See id. at 425-26.

146 For more detailed explanations of the "natural law" theory of copyright, see generally Tehranian, supra note 135, at 481; Wendy J. Gordon, A Property Right In Self-Expression: Equality And Individualism In The Natural Law Theory of Intellectual Property, 102 YALE L.J. 1533 (1993); Alfred C. Yen, Restoring the Natural Law: Copyright as Labor and Possession, 51 OHIO ST. L.J. 517, 523-24 (1990).

147 MONTALEMBERT, supra note 109, at 21. See also discussion supra Part III(a).

148 Noah Webster is best-known by history as the man responsible for the creation of the Merriam-Webster Dictionary. See Wikipedia, Noah Webster, http://en.wikipedia.org/wiki/Noah_Webster (last visited Mar. 10, 2006).

149 LETTERS OF NOAH WEBSTER 418 (Harry R. Warfel, ed., 1953).

150 Act of May 31, 1790, ch. 15, 1 Stat. 124 (1790), available at http://www.copyright.gov/history/1790act.pdf (emphasis added).

151 Dallon, supra note 2, at 427.

152 Wheaton v. Peters, 33 U.S. 591 (1834).

153 Id. at $121-22$. 
published, the only protection afforded to the author and publisher was that provided by the Act..$^{154}$

The House Reports to revisions of the copyright statutes in 1909, and case law decided in the wake of the 1976 Act, continued to recognize the "public benefit" as the principal rationale for the copyright privilege. ${ }^{155}$ The Supreme Court and the circuit courts of appeal continued to invoke this language in their opinions dealing with copyright issues. $^{156}$ The first real philosophical shift in Congress' thinking occurred in 1998, with the passing of the CTEA, an amendment to the Copyright Act of 1976. ${ }^{157}$ The CTEA extended all of the time periods involved in copyright considerably, ${ }^{158}$ which arguably contradicts the "public purpose" rationale; but the real significance of the CTEA was the underlying reasoning involved. For the first time, Congress seems to have recognized a "natural law" theory of copyright privilege over its constitutionally mandated and long-pedigreed "public purpose" rationale.

The Senate report on the passage of the CTEA discloses four main purposes for the passage of the act: (1) the harmonization of U.S. patents and copyrights with those in the EU, (2) the favorable impact this longer recognition would have on trade with other countries, (3) fairness to the authors, and (4) the stimulation of new works and the preservation of existing historical works. ${ }^{160}$ These final two justifica-

154 Id.

155 "The enactment of copyright legislation by Congress under the terms of the Constitution is not based upon any natural right that the author has in his writings ... but upon the ground that the welfare of the public will be served and progress of science and useful arts will be promoted by securing to authors for limited periods the exclusive rights to their writings." H.R. Rep. No. 60-2222, at 7 (1909), quoted in Sony Corp. of America v. Universal City Studios, Inc., 464 U.S. 417, 429 n.10 (1984); see also Harper \& Row Publishers, Inc. v. Nation Enters., 471 U.S. 539, 580 (1985) (Brennan, J., dissenting) (quoting H.R. Rep. No. 60-2222).

156 See Sony, 464 U.S. at 429 (noting that the "difficult balance between the interests of authors and inventors [lies] in [protecting] the control and exploitation of their writings and discoveries on the one hand, and [protecting] society's competing interest in the free flow of ideas, information, and commerce on the other....").

157 CTEA, 112 Stat. at 2827.

158 See S. REP. NO. 104-315, at 2-3 (1996). The CTEA:

amended the Copyright Act of 1976 . . . by extending the duration of existing and future copyrights by twenty years. The term of copyright for new works generally went from the life of the author plus fifty years, to the life of the author plus seventy years. The term of copyrights for works made for hire was also increased by twenty years, resulting in a term of the shorter of ninety-five years from publication or 120 years from creation.

Dallon, supra note 2, at 437 (footnotes omitted).

159 Id.

160 See S. REP. NO. $104-315$ at 3. 
tions are most concerning for proponents of the "public purpose" rationale of copyright, and are indicative of an overall paradigm shift in Congressional attitudes towards copyright in general.

The "fairness" argument is clearly (and mistakenly) rooted in a "natural law" theory of copyright. In spite of the official statement by Congress that its understanding of the term "limited times" requires it to ensure that copyright holders should be allowed to pass their copyrights down through at least one if not two generations of descendants, ${ }^{161}$ Professor Dallon rightly observes that:

American copyright law has never attempted to ensure copyright protection to benefit the author and two full generations of the author's descendents. The concept of ensuring protection for an author's grandchildren is literally foreign to American copyright law and ironically was imported from the European Union Directive from 1993. Significantly, continental European copyright law has a different theoretical basis than American copyright law; continental European copyright law is premised on the natural law property right theory of copyright rather than a utilitarian public benefit theory. The natural law or property right theory supports a different balancing of interests than does the public benefit theory and supports very long-even perpetual-copyright terms. ${ }^{162}$

161 See id. at 10-11. This reasoning is even criticized within the Senate Report itself. Senator Brown notes that:

[t]he phrase "limited times" has never been defined by the courts. Both the Register of Copyrights and the Commissioner of Patents and Trademarks argue that life-plus70 years is a limited time. The Register of Copyrights suggests it is within the discretion of Congress to determine what constitutes a limited time. We do have an idea of what "limited times" meant to the drafters of the Constitution: the original grants of copyright extended for a time far shorter than the extreme position taken in this bill. The length of the term is so long that it invites a court review.

Id. at 33. The Senator also posits that:

[t]he real incentive ... is for corporate owners that bought copyrights to lobby Congress for another 20 years of revenue-not for creators who will be long dead once this term extension takes hold. Do you know any creator that would fail to create if the monopoly grant ran out at life-plus-50 years of protection rather than life-plus-70 years? Would Hemingway have produced another work if he were guaranteed another 20 years of copyright protection? Would Wyeth have painted more? Would Sinatra have sang more? This suggestion is ludicrous.

Id. at 32 .

162 Dallon, supra note 2, at 443-44 (footnotes omitted). 
The argument that an extension of copyright terms would stimulate the production of new works and preserve existing works is also based on a set of mistaken premises. The first part of this argument assumes that the sole motivation for creating expressive works is income. ${ }^{163}$ Even if generating income is a primary motivation for the artist, it seems unlikely that an extension of copyright to 70 years after his death would provide an incentive to create more or better works than he would have otherwise..$^{164}$ The second part of this argument is also countermanded by experience dating back to Jewish law showing that works may be better preserved by copying them as much as possible, or at least without restraint. ${ }^{165}$ In short, at least two of the premises upon which the CTEA is based seem to derogate the "public benefit" rationale envisioned by the Founding Fathers and enshrined in the Copyright Clause. The public is hardly served by allowing copyright holders to hoard their works from the public for longer than necessary.

Nevertheless, the Supreme Court ratified Congress's reasoning in Eldred v. Ashcroft. ${ }^{166}$ Applying a rational basis test to Congress's extension of copyright terms, the Court held that "it is generally for Congress, not the courts, to decide how best to pursue the Copyright Clause's objectives. ${ }^{, 167}$ As a result of this ruling, Congress has for the most part been left to its own devices. Congress gets to decide for itself what the Copyright Clause means, and needs only provide some rational reason for any modification it makes to existing copyright

163 See discussion infra Part III(b).

164 See S. Rep. No. 104-315 at 33.

165 "Endorsing and commanding faithful copying of texts" was one way the Judaism has been able to exist for 4,000 years in spite of its extreme diaspora. See generally DIMONT, supra note 108. One entertainment industry insider opined that:

[w] hatever work is not owned is a work that no one protects and preserves.... There is no one who will invest the funds for enhancement because there is no longer an incentive to rehabilitate and preserve something that anyone can offer for sale. A public domain work is an orphan. No one is responsible for its life. But everyone exploits its use, until that time certain when it becomes soiled and haggard, barren of its previous virtues. How does a consumer benefit from the steady decline of a film's quality?

The Copyright Term Extension Act of 1995: Hearing on S. 483 Before the Senate Comm. on the Judiciary, 104th Cong. 42 (1995). Obviously, history and experience seem to suggest precisely the opposite regarding the public domain's ability to preserve works for posterity. Aside from the Hebrew law governing the copying of texts, it is worth noting that "classic" novels and other works that have long-since passed into the public domain continue to be successfully and profitably reprinted and marketed in spite of the fact that these works can be exploited by anyone.

166537 U.S. 186 (2003).

167 Id. at 212. 
law. ${ }^{168}$ If Congress chooses to adopt a "natural law" theory that promotes the private interests of artists over the public interest in having access to useful works, there is little, from a constitutional standpoint, that any court can do to stop it. It is important to note that choosing to apply this test was not necessarily a mistake by the Supreme Court. The Court saw this as a simple case of how much it should infringe on a power constitutionally given to Congress, and chose to apply a standard of rational review that is frequently applied in the case of Article I powers. ${ }^{169}$ The issue, however, is how Eldred affects the underlying premise that copyright protections are intended primarily for the "public benefit" and not primarily for the "private benefit" of the artist.

All of this leaves us with two important points. First of all, copyright law was developed primarily to meet the needs of printers, publishers and distributors. Whether this is because governments were interested in the idealistic goal of having a ready supply of books available for their citizens, or the more sinister goal of controlling what books citizens would ultimately be able to read, one thing is clear: the benefits provided, historically, were not just designed to compensate artists, they were provided so that artists would be able to persuade publishers to make a capital investment with a governmentendorsed monopoly.

The second major point is narrower. The Copyright Clause of the U.S. Constitution is, like the rest of that document, designed to be selflimiting. In the United States, the government-endorsed monopoly power is (or should be) only as good as the expressive creation it incentivizes. Where the monopoly is not incentivizing creation and dissemination or where the monopoly is disincentivizing creation and dissemination, this may even suggest that even under an Eldred standard, the grant of monopoly is irrational. This understanding is consistent with the understanding of the Founding Fathers.

168 In the Senate Reports on the CTEA, Congress elaborated on its four principal justifications, stating that:

[t] he question of exactly what term of protection most appropriately reflects a "limited time" as envisioned by the Founders has been debated since the enactment of the first Copyright Act in 1790, and is likely to continue to be debated into the foreseeable future. Congress has long accepted the general principal, however, that copyright should protect the author and at least one generation of heirs.

S. REP. NO. 104-315 at 10.

169 Eldred, 537 U.S. at 208 (declaring that once "we find that the CTEA is a rational enactment; we are not at liberty to second-guess congressional determinations and policy judgments of this order, however debatable or arguably unwise they may be."). 
The Copyright Clause is designed to primarily benefit the public, followed, in a limited sense, by the artists. Copyright holders like record companies were important beneficiaries who were worth protecting when they served the public interest by disseminating music to the public, but like milkmen, their importance has waned with the advent of P2P file sharing. Now, instead of being a necessary spoke in a music distribution system, they stand in its way, waving copyrights that were designed for a pre-P2P world and litigating furiously against those who recognize their irrelevance.

\section{B. Commercial Copying: The Heart of Infringement}

As was discussed in the previous section, copyright law, at its historical core, is rooted in the commercial interest of publishing. What makes $\mathrm{P} 2 \mathrm{P}$ file sharing unique in the history of copyright law is not only its ability to copy, but its ability to disseminate without the need for any kind of publishing. The historical record demonstrates that a major focus of copyright law from its inception has been to protect the interests of publishers, because the protection of those interests was the surest route to dissemination. In the digital age, there is, for the first time, no significant cost associated with dissemination; and the job that used to belong to a publishing house now belongs to every person who uploads and downloads music. In effect, the needs of artists, the public, and the publishers are no longer really aligned because publishers impose what amounts to a surplus cost on music recordings that is no longer needed to ensure dissemination.

The 1976 Act takes very well-defined and comprehensive steps to prevent commercial piracy of "phonorecordings,", to remember that the environment we are in now is one that was not contemplated by the drafters of the act in 1976. At that time, it was probably assumed that almost all piracy would have an inherently commercial character. After all, who would go through the time and effort of pressing and packaging an album in order to just give it away to people? Naturally, this behavior didn't really make sense in a nondigital environment, so it was probably not foremost on the minds of the drafters of the 1976 Act.

This emphasis on underlying commerciality receives support from several sources in the 1976 Act, which provides a number of exceptions to infringement based on uses that are private and not strictly commercial. ${ }^{171}$ Often uses made for what is considered a "public" pur-

170 The Copyright statute defines this term. See 17 U.S.C. $\$ 101$ (2000).

171 See, e.g., 17 U.S.C. $\$ 111$ (2000) (exempting private secondary transmissions within businesses where such transmissions are not being sold); 17 U.S.C. $§ 119$ (2000) (exempting second- 
pose, such as library-based copying, are not considered infringing. ${ }^{172}$ An excellent example of this kind of exception-making is section 602(a)(2) of the 1976 Act, which dictates that:

importation, for the private use of the importer and not for distribution, by any person with respect to no more than one copy or phonorecord of any one work at any one time, or by any person arriving from outside the United States with respect to copies or phonorecords forming part of such person's personal baggage. . . . is not an act of infringement.

This has two significant effects in a P2P file-sharing context. First, what if the party offering the upload is international? Doesn't that relieve the downloading party, who is downloading "no more than one copy ... of any one work at any one time[,]" from liability under the exception? Is downloading importation within the meaning of the copyright clause? There is no case law on this point, but it would certainly seem plausible.

The second effect is on direct sites that offer music for download, like Allofmp3.com, and its different-in-name-only descendant, Mp3Sparks.com. ${ }^{174}$ Allofmp3.com operated in a "grey area" with respect to the legitimacy of its service to Russian downloaders. ${ }^{175}$ The owners of the site claimed ownership of their files by virtue of the fact that Russian copyright law gave them the right, as owners of Russian radio stations, to "broadcast" their music on the Web and through radio waves. ${ }^{176}$ Russian authorities said the service provided by the company is illegal, and eventually shut down Allofmp3.com. ${ }^{177}$ The

ary transmissions of superstations and public broadcasting stations for private home viewing); 17 U.S.C. $\$ 602$ (2000) (exempting importation of otherwise infringing nondramatic musical works for the private use of the owner).

172 See, e.g., 17 U.S.C. $\$ 108$ (2000) (providing a special set of exemptions for photocopying by libraries); 17 U.S.C. $\$ 407$ (2000) (allowing "deposit" exceptions for the library of Congress); 17 U.S.C. $\$ 504(c)(2)$ (2000) (allowing reduced statutory damages for library employees acting within the scope of their employment).

17317 U.S.C. $\$ 602(\mathrm{a})(2)(2000)$.

174 AllofMP3 Home Page, http://www.allofmp3.com (last visited Mar. 11, 2006); Mp3Sparks Home Page, http://mp3sparks.com/ (last visited May 29, 2008). Russian authorities ultimately agreed to shut down AllofMP3.com because it presented a stumbling block to the country's WTO membership. Mp3Sparks sprung up days later, with exactly the same content, and has been running ever since. See Mike Masnick, RIAA Drops Allofmp3 Lawsuit; Pretends Mp3Sparks Doesn't Exist, TECHDIRT (May 27, 2008), available at http://techdirt.com/articles/20080527/0044331223.shtml.

175 Dana Malhauser, Barely Legal - The Hottest Trend in File Sharing, SLATE (Mar. 28 2005), available at http://www.slate.com/id/2115868/.

176 See id.

177 See id:; but see, supra, note 174. 
service charged roughly a penny a megabyte to download copies of popular artists from the United States and Europe. ${ }^{178}$ Naturally, it is unclear whether any part of that cost was distributed to copyright holders, since the site existed in Russia, but it was (and is) likely that Allofmp3.com (and, for that matter, Mp3Sparks.com) is just working within the confines of a compulsory licensing system very different from our own. Once again, does the "importation exception" make downloading "no more than one copy. . . of any one work at any one time" legal under our 1976 concepts of infringement? ${ }^{179}$ It would certainly seem so.

There are really only two possible conclusions that can be drawn from the presence of section 602(a)(2) in the Copyright Act: either (1) the Act is simply not that concerned about private noncommercial importation of music, or (2) the writers of the Act did not really consider the impact of a large scale, online importation system, and therefore they did not deal with it. In either sense, it would seem that the Copyright Act of 1976 is ill-equipped to deal with the realities of the file-sharing controversy.

Another example of the Act's deficiencies is the statutory penalty imposed for infringement. The Copyright Act gives copyright holders the option to recover actual damages plus defendant's profits made by an infringer, or forego those damages in favor of statutory damages. One would assume that a need for statutory damages would arise where actual damages were difficult or impossible to prove, but they are unfortunately available, like an unconscionable liquidated damages clause, where little or no actual damages have occurred.

Section 504(c)(1) of the Copyright Act guarantees statutory damages, should a plaintiff elect them, of "a sum of not less than $\$ 750$ or more than $\$ 30,000$ as the court considers just." Consider the amount of actual damages that may exist with respect to the downloading of a single CD: $\$ 15.99$ per $C D$, divided across 13 songs on that $C D$, is about $\$ 1.23$ per song. Allowing the plaintiff to elect statutory damages of $\$ 750$ per song or per album, when actual damages could easily be calculated at somewhere between $\$ 1.23$ and $\$ 15.99$, seems excessive. Even under Eldred's rational review standard, these damages may not survive. One argument in favor of these large statutory penalties might be that they act as deterrents, but if the effect of a deterrent is to force a beneficiary of the copyright clause, the public, to pay an extra amount of money which is not ultimately going to wind up in the

178 See generally AllofMP3.com Home Page, http://www.allofmp3.com (last visited Mar. 11, 2006).

17917 U.S.C. $\$ 602(a)(2)(2000)$. 
hands of the artist, aren't we really asking the public, via the statutory penalty, to subsidize an outmoded means of production?

The existence of the a statutory penalty of this magnitude forces us to consider two possible conclusions: Perhaps the size of the damage provision is due to the fact that it was designed primarily to deter commercial pirates, therefore it would not be applicable to a noncommercial downloader; or perhaps Congress simply did not anticipate how the Act would function in a digital culture, and therefore the act is ill-equipped to deal with these questions. In either case, there is evidence within the Copyright Act itself that allows us to conclude that its statutory provisions may not be the best guide to interpreting copyright law, perhaps it would be better to rely on the underlying policies of copyright law to guide our conclusions.

\section{The Beneficiaries that Weren't: Artists and the Public}

As noted above, the Constitution is the root of our copyright, and the Copyright Clause itself neatly demonstrates that the copyright holder's statutory monopoly is granted in order "to promote the progress of science and the useful arts." ${ }^{, 180}$ The clause therefore demonstrates a "purpose" of promoting progress and a "method" of granting copyrights for limited times. ${ }^{181}$ The main problem with the "natural law" theory of copyright, which seems to have been adopted by Congress in the passing of the CTEA ${ }^{182}$ is that it confuses the purpose with the method. The statutory monopoly is not an end in and of itself. It is a means of encouraging creation by artists and dissemination by (until now) publishers.

There are really only two ways to promote the "progress" of the useful arts in a manner that benefits society: works must be created and works must be broadly disseminated. These goals seem antithetical, after all, the best way to maximize dissemination would be to make all works available for free, while theoretically, the best way to maximize the incentive for creation would be to protect works in perpetuity. ${ }^{183}$ It is important, however, to remember that the Founding Fathers did not care for monopolies in general, and at least some of them had their reservations about a government-backed statutory

180 U.S. CONST. art. I, $\S 8$, cl. 8.

181 See Dallon, supra note 2, at 367-68.

182 The CTEA is addressed in detail in Part III(a) of this comment.

183 Perpetual protection (or even longer protection terms) may in fact encourage less works by successful artists. Shorter Copyrights could "inspire" artists to create new works to replace their income from expiring copyrights. 
monopoly for copyright holders. ${ }^{184}$ But the Copyright Clause was ultimately approved because the Founding Fathers thought that the monopoly would be used for the public benefit.

Looking at the current state of the record industry, the concerns of the Founding Fathers seem (pardon the pun) well-founded. This industry has had every kind of consumer complaint lodged against it over the years: including widespread payola scandals, ${ }^{185}$ and antitrust litigation for, among other things, fixing the price of CDs in order to charge the public an unfair rate. ${ }^{186}$ It is clear that the record industry does not exactly act, of its own accord, with the best interests of its public at heart. At the other end of the spectrum, artists have complained about the unfair nature of recording contracts for years. ${ }^{18}$ Even the standard industry contract hardly puts the artist at any kind of advantage right out of the gate. ${ }^{188}$ In the words of artist Courtney Love:

[s]omewhere along the way, record companies figured out that it's a lot more profitable to control the distribution system than it is to nurture artists. And since the companies didn't have any real competition, artists had no other place to go. Record companies controlled the promotion and marketing; only they had the ability to get lots of radio play, and get records into all the big chain store[s]. That power

184 See THE REPUBLIC OF LETTERs supra note 144, at 566; COHEN, supra note 140, at 23940; See also infra notes 137-144 and accompanying text.

185 See Eric Boehlert, Will Congress tackle pay-for-play?, SALON (Jun. 25 2002), available at http://www.salon.com/ent/feature/2002/06/25/pfp_congress/index.html (last visited Mar. 10, 2006).

186 See Barry Willis, FTC: No More Minimum Advertised Pricing on CDs, STEREOPHILE (May 14 2000) (last visited Mar. 11, 2006) (detailing the record industry's agreement to rescind is "MAP" program of retail price-fixing). Unfortunately, the Justice Department does not seem to be able to stop the record industry from engaging in antitrust violations. For a more current version of this issue, see Sue Ziedler, DOJ opens probe into online music pricing, REUTERS (Mar. 3, 2006).

187 In fact, the most successful artists who are making serious amounts of money in the music business do so principally through live concerts and brand-building, not the sale of records. Rolling Stone Editor Joe Levy notes that "[ $\mathrm{t}$ ]he biggest-selling artists [in terms of record sales] aren't the ones who make the most money. The artists learn the hard way that money comes from concert tickets and T-shirts, not selling records." John Leland, Balding Rockers and Big Money, N.Y.TIMES, Feb. 13 2005, at 4.7.

188 See Steve Albini, The Problem with Music, http://www.negativland.com/albini.html (criticizing the way the record industry deals with its artists) (last visited Mar. 16, 2006); see also Future of Music Coalition, Major Label Contract Clause Critique (Oct. 3, 2001), available at http://www.futureofmusic.org/contractcrit.pdf (conducting a point-by-point examination of a major label contract for clauses biased in favor of record companies over artists) (last visited Mar. 16, 2006). 
put them above both the artists and the audience. They own the plantation.

Artist Janis Ian puts this problem into a more personal perspective, pointing out that "in 37 years as a recording artist, I've created $25+$ albums for major labels, and I've never once received a royalty check that didn't show I owed them money." $" 190$

This is the price that the public and the artist pays for an "oldstyle" physical dissemination network. It is a price that is too high in an environment where the primary function of the record label is no longer necessary. Of course, it is not up to the courts to change the statutes. Under the United States Supreme Court's precedent in Eldred, courts can only subject congressional interpretations of the Copyright Clause like the 1976 Act to "rational review." While this level of review may be enough to overturn the excessive penalties provided by the Act, it is doubtful the court will adopt a new meaning of what constitutes infringement in the digital environment.

\section{FAIR USE: INCENTIVES, ACCESS, AND THAT SILlY OLD CONSTITUTION}

Fortunately, interpretations of the copyright clause are not left completely to the whims of Congress. Courts, over time, have developed the doctrine of "fair use" to undo the harshness of the statutory copyright regime when necessary. Principally defined as a "privilege in others than the owner of a copyright to use the copyrighted material in a reasonable manner without consent, notwithstanding the monopoly granted to the owner[,]"191 this doctrine has co-evolved with copyright doctrine over time. As new technologies have emerged, fair use has been allowed to evolve-as a defense to a copyright infringement claim - to encompass the use of technologies in a manner beneficial to society at large.

\section{A. Historical Precursors to Fair Use}

Historical antecedents constituting what could be termed as a fair use argument go as far back as medieval Ireland. Although no official record exists in the matter of Finnian v. Columba, historians have noted that Columba's defense to Finnian's claim that he had made an

189 Courtney Love, Address at Digital Hollywood Online Entertainment Conference (May 16, 2000), available at http://www.salon.com/tech/feature/2000/06/14/love/ (last visited Mar. 16 2006).

190 Ian Article, supra note 95.

191 Horace Ball, The LAW of COPYRIGHT AND Literary Property 260 (1944). 
unauthorized copy of his old master's psalter was essentially that such copying should be considered a fair use. ${ }^{192}$ Columba pointed out that:

Finnian's book has not decreased in value because of the transcript I made from it; also that it is not right to extinguish the divine things it contained, or to prevent me or anybody else from copying it, or reading it, or circulating it throughout the provinces. I further maintain that if I benefited by its transcription, which I desired to be for the general good, provided no injury accrued to Finnian or his book thereby, it was quite permissible for me to copy it! ${ }^{193}$

"Fair use" also figured prominently in English interpretations of the Statute of Anne. Both Newbery's Case and Donaldson v. Beckett illustrated the English Courts' willingness to get involved in balancing the public benefit provided by a work with the harshness of the copyright statute. The rule under English common law was called the "fair abridgment" rule, and, not surprisingly, it applied to abridgments only, which were seen as enhancing the public benefit offered by a particular work.

The American doctrine of fair use emerged in the case of Folsom v. Marsh. ${ }^{195}$ In Folsom, the defendant, writing a biography of George Washington, used a number of previously unpublished letters the plaintiff had procured and published in his own biography of the late president. ${ }^{196}$ The defendant did not engage in verbatim copying of the plaintiff's novel; he merely used the letters as "ingredients" in his own work, which Justice Story characterized as "an exceedingly valuable book." Ultimately, the court set forth a set of criteria that would be used to decide whether a "fair use" should be applied to a given case in the future, stating that:

[i]n short, we must often ... look to the nature and objects of the selections made, the quantity and value of the materials used, and the degree to which the use may prejudice the sale, or diminish the profits, or supersede the objects, of the original work ....

192 See Lucy MenZIES, SAInT COlumba Of IONA: A STUdy OF His LifE, His Times, \& His INFLUENCE 25 (1920).

193 Id. (this argument was ultimately unsuccessful).

194 See Newbery's Case, 98 Eng. Rep. at 913 (congratulating Newbery for reducing Hawkesworthe's work to a more portable and readable form).

195 Folsom v. Marsh, 9 F. Cas. 342 (C.C.D. Mass. 1841) (No. 4,901).

196 Id. at 346.

197 Id. at 348 .

198 Id. 
This statement represents the foundation of the "four factors" that courts will look to in determining whether there is a fair use defense to a copyright infringement claim.

In spite of the fact that Justice Story laid out the fundamentals of fair use in Folsom, a number of scholars have claimed that he engaged in what amounted to a "natural law" interpretation of copyright which was not supported by the history of "fair abridgment" or the underlying "public benefit" of the copyright clause. e $^{200}$ Justice Story, in his holding, noted prominently that " $[\mathrm{t}]$ he entirety of the copyright is the property of the author; and it is no defense, that another person has appropriated a part, and not the whole, of any property.", ${ }^{201}$ Justice Story showed little regard for the public benefit that could be derived from the defendant's copying of the plaintiff's work. By emphasizing the property rights and limiting the application of fair use to what could be termed only as a "productive use," Justice Story went against the venerable English common law tradition that served as the basis of the Constitutional Copyright Clause. Professor Tehranian notes that "Story's legal analysis shows little regard for the potential benefit that dissemination of the allegedly infringing work may have for society[,]" which, if one takes the Copyright Clause seriously, should be a fundamental consideration in any analysis of fair use. ${ }^{202}$ In spite of these scholarly criticisms of the Court's analysis in Folsom, the fair use rationale set forth by Justice Story has been consistently applied and expounded upon in future cases and in future congressional acts.

\section{B. Noncommercial Activity: Fair Use under the 1976 Act}

The factors listed by the court in Folsom have been codified by Congress in the Copyright Act of $1976 .^{203}$ Congress set forth four factors that must all be considered by the court in the adoption of a fair use defense:

(1) the purpose and character of the use, including whether such use is of a commercial nature or is for nonprofit educational purposes; (2) the nature of the copyrighted work; (3) the amount and substantiality of the portion used in relation to the ... work as a whole; and (4) the effect of the use

\footnotetext{
199 See discussion infra Part IV(b).

200 See Tehranian, supra note 135, at 481.

201 Folsom v. Marsh, 9 F. Cas. 342, 348 (C.C.D. Mass. 1841) ( No. 4,901) (emphasis added).

202 Tehranian, supra note 135 , at 482.

20317 U.S.C. $\$ 107$ (2000).
} 
upon the potential market for or value of the copyrighted work. $^{204}$

These four factors were not intended by Congress to be exclusive, and courts have been given license to consider any other factors they may deem relevant on a case-by-case basis. ${ }^{205}$ The House reports on the legislative history of the fair use codification demonstrate that Congress did not intend to "freeze" the doctrine of "fair use," but merely intended to promulgate a set of guidelines for the courts to follow in their interpretations. ${ }^{20}$

In its preamble, the Act gives several examples of uses that could be considered "fair" by the courts, including "criticism, comment, news reporting, teaching (including multiple copies for classroom use), scholarship, or research ..... ${ }^{207}$ The examples listed by Congress are purposefully broad, and are by no means meant to be the outer limits of what uses could be considered "fair." The uses set forth by Congress in the preamble could all be considered "productive" or "transformative" uses, where the individual using the copyright is "adding something" to the copyrighted work, as opposed to "reproductive" uses, in spite of the fact that the public can benefit just as much from "reproductive" uses as from "productive" uses.

\section{The Purpose or Character of the Use}

This first factor principally focuses on the distinction between "commercial" and "non-commercial" uses and is designed to protect a copyrighted work from commercial exploitation by a non-copyright holder. ${ }^{209}$ Keeping with the Court's interpretation in Folsom, however,

\footnotetext{
204 Id.

205 In its House Report on the Copyright Act of 1976, Congress notes that:
}

[a]lthough the courts have considered and ruled upon the fair use doctrine over and over again, no real definition of the concept has ever emerged. Indeed, since the doctrine is an equitable rule of reason, no generally applicable definition is possible, and each case raising the question must be decided on its own facts. On the other hand, the courts have evolved a set of criteria which, though in no case definitive or determinative, provide some gauge for balancing the equities.

H.R. Rep. No. 94-1476, at 66 (1976).

206 See id.

207 17 U.S.C. $\S 107$ (2000).

208 In fact, the U.S. Supreme Court, in Sony Corp. v. Universal City Studios, Inc., 464 U.S. 417 , 421 (1984), implicitly rejected an earlier holding by the Ninth Circuit based on a "productive use" theory. See Universal City Studios, Inc. v. Sony Corp. of Am., 659 F.2d 963, 970 (9th Cir. 1981), rev'd, 464 U.S. 417 (1984).

209 See Ass'n of Am. Med. Colls. v. Mikaelian, 571 F. Supp. 144, 151-53 (E.D. Pa. 1983) (holding that the defendant was unable to show an educational purpose for his fair use defense where 
a commercial purpose does not completely render it impossible for the court to find a fair use defense, but "a court should not strain to apply a fair use defense when it is being invoked by a profit-making defendant ...." ${ }^{210}$ For this reason, non-profit educational uses will generally create a presumption satisfying this factor, while uses that produce a profit for the non-copyright holder generally will not. ${ }^{211}$

The "purpose or character" factor also addresses "bad faith" uses:

where a defendant has knowingly exploited a stolen manuscript or engaged in verbatim copying without any effort to obtain permission from the copyright owner or cite the copyright owner as the source of the material. ${ }^{212}$

A finding of "bad faith," like a finding of "commercial purpose," is not dispositive as to whether a use is ultimately fair. It merely weighs for or against a defendant in conjunction with other factors found to be important by the court. ${ }^{213}$ In addition, the "purpose or character" factor addresses whether "comment and criticism" was a primary motivation for a use. ${ }^{214}$ "However, an individual in rebutting a copyrighted work containing derogatory information about himself may copy such parts of the work as are necessary to permit understandable comment." 215

\section{The nature of the copyrighted work}

When evaluating the nature of copyrighted works, courts are more likely to allow fair uses of material that is informative in nature than that which is expressive in nature, although, like any other factor,

he collected questions from medical course books for inclusion in a commercial preparatory booklet); Twin Peaks Prod., Inc. v. Publ'ns, Int'l, Ltd., 996 F.2d 1366, 1370 (2d Cir. 1993) (holding the defendant liable, in spite of his argument for an "educational purpose" fair use, where he copied plot details from plaintiff's show for his book).

210 Mikaelian, 571 F. Supp. at 153.

211 See Princeton Univ. Press v. Michigan Document Servs., 99 F.3d 1381, 1388-89 (6th Cir. 1996) (noting that even where a defendant's customers would have a fair use defense showing a nonprofit educational purpose, that defense will not be available to a defendant who takes "orders" to copy for commercial gain).

212 MARShAll LeAFFer, Understanding COPYRIGHT LAW 477 (2005); see also Harper \& Row Publishers, Inc. v. Nation Enters., 471 U.S. 539, 562 (1985) (noting that "the propriety of the defendant's conduct" is relevant to the first fair use factor).

213 NXIVM Corp. v. Ross Inst., 364 F.3d 471, 476-77 (2d Cir. 2004) (holding that the defendants, who copied the plaintiff's copyrighted material in order to criticize their "cult," were engaged in a fair use, in spite of the fact that the defendants knew they were not authorized to access the plaintiff's work).

214 See Hustler Magazine v. Moral Majority, Inc., 796 F.2d 1148, 1153 (9th Cir. 1986) (noting that "Section 107 expressly permits fair use for the purposes of criticism and comment.").

215 Id. 
a finding that a work is expressive will not completely eliminate a fair use defense. ${ }^{216}$ This factor could be characterized as an embodiment of the "public benefit" rationale, allowing wider uses for scientific, biographical or historical works than those which are purely expressive in nature than for those which are purely expressive, such as rock concerts. ${ }^{217}$ This factor also addresses a work's accessibility to the public. Where works are more accessible to the public, the need for fair use decreases, but where they are less accessible, the need for fair use is likely to increase. ${ }^{219}$

\section{The amount or substantiality of the portion used}

This factor, which is most often applied in relation to fair uses involving comment and criticism, asks whether the non-copyright holder took more than the amount of a copyrighted work than he needed. ${ }^{220}$ Where a non-copyright holding author has taken more of a copyrighted work than he needs for his critical points, he will abrogate a defense under fair use.

Because it deals with "amount and substantiality," this factor forces courts to evaluate the quality as well as the quantity of the work used by a non-copyright holder. ${ }^{222}$ Where an author, even through a small amount of copying, has essentially copied the essence of a copyrighted work, this factor will not be satisfied, even if the overall amount of the work copied is small in nature. ${ }^{223}$ The concern, which relates closely to the fourth factor, ${ }^{224}$ is that if a non-copyright holder engages in too much copying of a copyrighted work, the public's need for the copy may wind up displacing the need for the origi-

216 See Sony Corp. of Am. v. Universal City Studios, Inc., 464 U.S. 417, 496-97 (1984) (holding that time-shifting television programs was a fair use that relieved the petitioner of liability in spite of the fact that "informational works ... are less protected than creative works of entertainment[, and] Sony's own surveys indicate that entertainment shows account for more than $80 \%$ of the programs recorded by Betamax owners.").

217 See LEAFFER, supra note 212, at 478.

218 See H.R. Rep. No. 94-1476, at 71.

219 See id.

220 See Craft v. Kobler, 667 F. Supp. 120, 128 (S.D.N.Y. 1987) (noting that "the Supreme Court ... employed a qualitative rather than a numerical assessment" in assessing the amount and substantiality argument); Sony, 464 U.S. at 496-97 (allowing a fair use defense in spite of the fact that the "time-shifting" involved entire programs).

221 See Harper \& Row Publishers, Inc. v. Nation Enters., 471 U.S. 539, 544 (1985) (holding that where the amount of a work taken was qualitatively the "heart" of a copyrighted work, the respondent failed under the "amount and substantiality" factor).

222 See id.

223 See id.

224 See Meeropol v. Nizer, 560 F.2d 1061 (2d Cir. 1977) (noting that factor three, "amount and substantiality of the work used, and [factor four,] its effect upon the potential market for the copyrighted material," are factors which should be evaluated together). 
nal, undermining the "method" of achieving the public benefit purpose cited under the copyright clause.

4. Effect of the use on the potential market for, or value of, the work

This factor examines whether a non-copyright holder's use of a copyrighted product will have a substantial effect on the market for the original copyrighted work. The standard rationale for the fourth factor relates closely to that for the third, "[i]f the market for the copyright owner's work is harmed, the incentives for creativity that the copyright monopoly is designed to encourage will not work.'

This factor focuses both on the actual market harm caused by a defendant's copying and on the potential harm a defendant's copying could have on the market for the author's copyrighted work. ${ }^{226}$ Courts consider not just the effect of an individual infringement on a given market (which would normally be quite small, especially where the use in question is a private use), but whether widespread conduct of the kind would wind up affecting the market negatively. ${ }^{227}$ Because of this "potential harm" rationale, courts are not obligated to consider whether a work has been marketed by a defendant or not. The ambit of "potential market harm" enables copyright holders to prevent defendants from claiming fair use by privately copying an author's copyrighted works. ${ }^{228}$ In order to defeat a defendant's fair use claim under this factor, a plaintiff only needs to demonstrate that there is a "meaningful likelihood of future harm.",229 A plaintiff does not need to show that he was actually harmed or would be harmed by a use in order to prevail against a defendant's fair use claim. In answering

225 LEAFFER, supra note 212, at 478. Notice that the rationale is stated in terms of copyright holders, not authors. What if this rationale was not true? Authors seemed perfectly willing to create works before copyright and they seem to be willing, even today, to create works in spite of the fact that financial rewards are extremely unlikely. Certainly copyright holders would be harmed by these uses, but the constitutional question is (or should be) whether, in the end, the public would have access to less works.

226 The Copyright Act creates a "wide berth" for the "market harm" factor by expressly stating market harm in terms of potentiality. See 17 U.S.C. $§ 107(4)$ (2000). Obviously, a showing of actual harm would, in itself, be conclusive as to whether there was potential harm, so it is safe to assume that actual harm would fall into the ambit of $\S 107(4)$. Id.

227 Courts should "consider not only the extent of market harm caused by the particular actions of the alleged infringer, but also 'whether unrestricted and widespread conduct of the sort engaged in by the defendant ... would result in a substantially adverse impact on the potential market' for the original.” Campbell v. Acuff-Rose Music, Inc., 510 U.S. 569, 590 (1994).

228 See Metro-Goldwyn-Mayer Studios Inc. v. Grokster, Ltd., 125 S. Ct. 2764, 2782 (2005) (finding "evidence of infringement on a gigantic scale" in spite of the fact that the evidence consisted of noncommercial copying by the service's users); A \& M Records, Inc. v. Napster, Inc., 239 F.3d 1017 (9th Cir. 2001) (affirming similar finding under a clear error standard).

229 LEAFFER, supra note 212, at 472. 
whether there is a "meaningful likelihood of future harm," courts generally address whether the market for the copy will significantly displace the market for the original. ${ }^{23}$

Appling the "purpose/method" rationale to this factor, it appears that the argument looks like this: Authors are encouraged to create and seek to publish new expressive works by the guarantee of a statutory monopoly under the Copyright Clause. The reason this monopoly is guaranteed is because the public derives a benefit from these new works. Therefore, any works that infringe on the monopoly necessarily infringe on the artist's incentive to create. This argument rests on two critical assumptions: (1) that authors create works principally for profit and (2) that the public benefit accrued by the wide use of existing works is somehow smaller than the public benefit accrued by the restriction of copying works. The problem is that the industry itself has proven the first assumption wrong; artists routinely create property that record companies are able to use to turn a substantial profit, but that profit does not find its way back to the artist. ${ }^{231}$ Somehow, this does not seem to disincentivize creation. The second assumption can be attacked on two points: (a) imposing a limitation on P2P distribution not only imposes a limitation on copyright, but on technology as well, and (b) the axis of the balance, if one considers that the Copyright Clause is essentially a grant of monopoly endorsed by the government, should be, at default, in favor of the public interest in dissemination.

\section{Technology and Fair Use, the Push-Pull Relationship}

Courts have not adopted Congress's rationale of "productive use" altogether in their interpretations of what does and does not constitute a Fair use. Often, the most divergent interpretations of fair uses come on the heels of new technologies, such as copying machines, videocassette recorders, or Internet file-sharing networks. This section looks at each of those technologies in turn and examines how the court applied nontraditional methodologies to these uses in order to

230 In Kelly v. Arriba Soft Corp., 280 F.3d 934, 948 (9th Cir. 2002), the court notes that:

Kelly's markets for his images include using them to attract advertisers and buyers to his web site, and selling or licensing the images to other web sites or stock photo databases. By giving users access to Kelly's full-sized images on its own web site, Arriba harms all of Kelly's markets. Users will no longer have to go to Kelly's web site to see the full-sized images, thereby deterring people from visiting his web site.

Id.

231 See Albini, supra note 188. 
balance the "purpose" and "method" proscribed under the Copyright Clause.

\section{The photocopier}

The first case in which the Supreme Court dealt with a fair use involving photocopying equipment was Williams \& Wilkins Co. v. United States. ${ }^{232}$ In that case, the U.S. Government, through its National Institutes of Health ("NIH") and its National Library of Medicine, photocopied and distributed articles from medical journals to anyone who made a request for them. ${ }^{233}$ In a number of cases, the circulation of the medical journals was low, meaning that those seeking the articles did not have many practical alternative means of acquiring them. ${ }^{234}$ In spite of the fact that millions of pages had been photocopied and it was probable that the photocopies of the articles had inevitably found their way into a number of commercial uses, the Supreme Court did not disturb a lower court holding that the government's use of these medical journals was fair because the plaintiff had failed to prove its future harm adequately. ${ }^{235}$ The court also noted that the dictionary definition of "copy" was inadequate to address the meaning of the word "copy" put forth under the Copyright Act of $1909 .^{236}$ The court also noted that since the invention of the photocopier, a culture had developed among libraries where photocopying articles had become accepted, and this culture, to the extent that it advanced knowledge, was beneficial to the public. ${ }^{237}$

The courts seemed to scale back this rationale in American Geophysical Union v. Texaco ("Texaco"). ${ }^{238}$ The defendant in that case had a corporate policy of photocopying relevant journal articles from periodicals it purchased and storing them in a library for future use by its employees. $^{239}$ Although there was no direct commercial advantage in

232 Williams \& Wilkins Co. v. United States 487 F.2d 1345 (1973), aff'd, 420 U.S. 376 (1975). One interesting aspect of this case is that the relevant statute was the Copyright Act of 1909, not 1976. Williams \& Wilkins and its progeny seem to have wrought significant changes in the Copyright Act of 1976. See 17 U.S.C. $\$ 108$ (2000). Perhaps P2P file sharing will have the same effect on a future copyright act. If so, decisions involving P2P file sharing are likely to have an impact on the act's language.

233 Williams \& Wilkins, 487 F.2d at 1348 . The NIH did have a policy not to copy and distribute journals that were part of its widely available list and not to honor excessive requests from any single institution, but these policies had exceptions. Id. at 1349.

234 See id. at 1356.

235 Id. at 1358.

236 Id. at 1351.

237 See id. at $1355-56$.

238 American Geophysical Union v. Texaco, 802 F. Supp. 1 (S.D.N.Y. 1992); aff'd, 37 F.3d 881 (2d Cir. 1994).

239 Texaco, 802 F. Supp. at 4-5. 
the articles, the Second Circuit held that the defendant was not engaging in fair use because it could easily have purchased additional journal subscriptions instead of photocopying the journals and storing them away. ${ }^{240}$ Even though the defendant argued that its use was for research and that the burden of the extra transaction costs imposed upon the defendant by having to purchase additional journals would outweigh the benefit of its research, the fact that the research conducted by the defendant ultimately led to a commercial purpose was enough to hold it liable for infringement. ${ }^{24}$

In Princeton University Press v. Michigan Document Services, ${ }^{242}$ the court held that a defendant could not take excerpts from copyrighted books in order to profit, even when the purpose ultimately served was educational in nature. ${ }^{243}$ The facts in that case showed that the defendant, the owner of a small copy shop, was engaged in the business of creating "coursepacks" for professors at the University of Michigan. $^{244}$ The defendant did not seek permission from the copyright owners to create these coursepacks. ${ }^{245}$ The court held that this copying was not a fair use because by copying those works for profit, the defendant was clearly competing in a market for the copyrighted works. $^{246}$ This finding was made in spite of the fact that under the preamble language of the fair use doctrine as codified in section 108, the professors requesting these coursepacks could have gathered and copied the material on their own. ${ }^{247}$

The photocopier cases are interesting because they present a clear "case study" of how the fair use doctrine can be used to protect certain uses of new technologies. Photocopying law seems to have developed a "pattern" that courts should adopt for future technological advances like P2P: a new technology was created; in a legal vacuum, a "culture" formed around the use of the technology; under the "fair use" doctrine, a jurisprudence was allowed to develop around the culture; the market adjusted. This is a good way to create new doctrine without being overly restrictive or overly permissive. A second example exists with videocassette recorders.

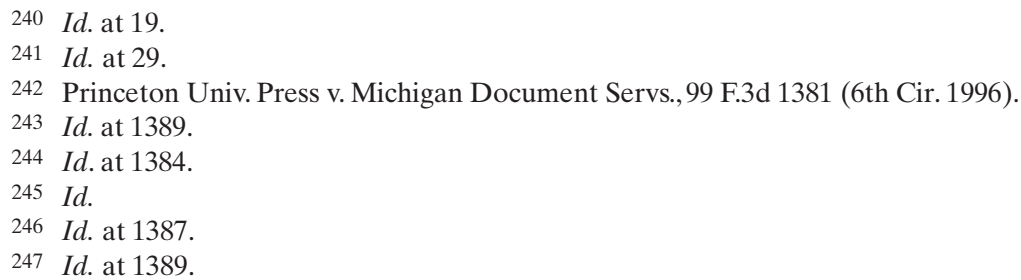




\section{The videocassette recorder}

In Sony Corp. of Am. v. Universal City Studios, Inc. ${ }^{248}$ the Supreme Court dealt principally with the issue of whether Sony, by creating and marketing a machine that was capable of copying television broadcasts, was liable as a contributory infringer. ${ }^{249}$ Because the Supreme Court held that the manufacturer of a product that was being used to infringe could not be liable so long as its product was capable of "substantial noninfringing uses," liability for contributory infringement rests implicitly on a finding of direct infringement by those using a product. Therefore, the Court was forced to deal with the sub-issue of whether a product's use constituted direct infringement. ${ }^{250}$ Writing for the majority, Justice Stevens held that the habit of "time shifting," that is, of users recording programs to watch later on at their leisure, was indeed a fair use because non-commercial uses placed the burden on the plaintiff to demonstrate that they could suffer potential harm, and the plaintiffs were unable to demonstrate that they suffered this harm. The defendant also proffered "library building" as a potential fair use, but the Supreme Court did not reach that question since it concluded (a) that the defendant's product need only be capable of a single fair use for Sony to avoid liability, and (b) that "time shifting" was just such a fair use.

Sony is significant for a number of reasons. First, it represents an abrogation by the Supreme Court of the Congressional doctrine of "productive use" as a basis for fair use. "The use by the directlyinfringing parties in Sony is purely reproductive in nature, lends a great deal of support to the holding in Williams \& Wilkins that not all reproductive uses will necessarily be unfair. ${ }^{254}$ Second, Sony seems to

248 Sony Corp. of Am. v. Universal City Studios, Inc., 464 U.S. 417 (1984).

249 Id. at 420.

250 Id. at 442.

251 See id. at 450-51 (noting that "a use that has no demonstrable effect upon the potential market for, or the value of, the copyrighted work need not be prohibited in order to protect the author's incentive to create. The prohibition of such noncommercial uses would merely inhibit access to ideas without any countervailing benefit.").

252 Id. at 442.

253 Id. at $455 \mathrm{n} .40$ (noting that "[t]he distinction between "productive" and "unproductive" uses may be helpful in calibrating the balance[in a determination of whether a given use is fair], but it cannot be wholly determinative. Although copying to promote a scholarly endeavor certainly has a stronger claim to fair use than copying to avoid interrupting a poker game, the question is not simply two-dimensional."); see also id. at 478 (Blackmun, J., dissenting) (criticizing the majority's rejection of the productive use standard).

254 Compare id. at 455 n.40, with Williams \& Wilkins Co. v. United States 487 F.2d 1345, 1353 (1973) (noting that "[i]t has sometimes been suggested that the copying of an entire copyrighted work ... cannot ever be "fair use," but this is an overbroad generalization, unsupported by the decisions and rejected by years of accepted practice."). 
imply a stronger presumption to private noncommercial uses, at least where the initial product is free. No one argued in Sony that the entire audience was engaged in an educational purpose. ${ }^{255}$ Indeed, the nature of the works in the majority of cases were clearly expressive, and not informational. ${ }^{256}$ In spite of that, the Court in the Sony ruled that there was no direct infringement done by time-shifting.

So where does this leave fair use? It seems that the doctrine is suffering from divergent trends. Sony and Williams \& Wilkins seem to suggest that private noncommercial uses can be okay. ${ }^{258}$ Sony, in fact, seems to reach even farther because the vast majority of television programs are "expressive," rather than "informative" works. ${ }^{259}$ Texaco and Princeton both seem to come down fairly hard on commercial uses, but it is important to remember that they do not really reach the question of whether those same uses would be okay in a noncommercial sense.

In the file-sharing context, the difference seems to be one of scale. The Ninth Circuit rejected the fair use arguments made by the defendants in Napster, but the deciding factor seemed to be the potential availability of the copyrighted material was something which rendered the end-users' approach unfair, especially in the context of Rio's seeming ratification of the same "space shifting" argument made by the defendants in Napster. ${ }^{261}$ Grokster, however, could be seen as something more akin to direct commercial infringement. The respondent in that case clearly made a profitable use of others copyrighted material in spite of the fact that it never uploaded the material onto its

255 See generally Sony, 464 U.S. 417.

256 Id.

257 Id. at 442.

258 See id (allowing noncommercial time shifting); Williams \& Wilkins, 487 F.2d at 1353 (allowing noncommercial photocopying).

259 See Litman, supra note 15, at 24-25 (discussing the elusiveness of the distinction between information and expression and suggesting that the underlying arguments for distinguishing these two ultimately fail).

260 See Texaco, 802 F. Supp. 1 (holding that copying journal articles was not a fair use because Texaco was ultimately using their contents for a commercial purpose); Princeton University Press v. Michigan Document Services, 99 F.3d 1381 (6th Cir. 1996) (holding that a business that produced "coursepacks" which included copyrighted material was unfairly profiting from other artists' copyrights and thus was not engaged in a "fair use").

261 Compare A\&M Records, Inc. v. Napster, Inc., 239 F.3d 1004, 1020 (9th Cir. 2001) (finding no merit in Napster's “space shifting” argument), with Recording Industry Ass'n of America, Inc. v. Diamond Multimedia Systems, Inc., 180 F.3d 1072, 1079 (9th Cir. 1999) (noting that "[t]he Rio merely makes copies in order to render portable, or "space-shift," those files that already reside on a user's hard drive[]" and that "[s]uch copying is paradigmatic noncommercial personal use entirely consistent with the purposes of the Act"). 
website; the task of engaging in actual infringement was left to the users who inhabited the network. ${ }^{262}$

There is another interesting aspect to consider when looking at the line of $\mathrm{P} 2 \mathrm{P}$ cases in comparison to photocopying and videocassette recorder cases. P2P cases seem, by necessity, to involve a morass of infringement standards for contributory, vicarious, direct, and recently "inducement" liability. ${ }^{263}$ This extensive importation and use of standards that are not expressly mentioned in the Copyright Act strongly suggests that P2P technology has outstripped the statutory language.

Ordinarily, courts treading on what is clearly new ground would show great deference to Congress and the public's interest in leaving new technologies unfettered, but unlike the courts in the photocopier and videocassette recorder cases, courts judging liability in $\mathrm{P} 2 \mathrm{P}$ seem to have lost sight of the "public purpose" rationale and the idea that Congress should be the entity deciding how to deal with P2P. Courts in $\mathrm{P} 2 \mathrm{P}$ cases seem principally concerned with protecting of an imagined property right over the reproduction of published music. Such an interpretation is not supported by history. ${ }^{265}$ Instead courts should police these new technologies carefully, with an eye towards maintaining maximum dissemination and technological development while ensuring that enough is left to incentivize creation.

\section{Reinstating the Public Benefit Rationale via The Fair Use Doctrine}

Modern interpretations of the Copyright Clause, in both a legislative and judicial sense, seem to suffer from two principal evils, confusion and amnesia. The first evil is confusion between the "purpose," achieving a public benefit, and the "method," the granting of statutory monopolies. ${ }^{266} \quad$ The second evil is amnesia regarding the underlying history of the copyright clause. ${ }^{267}$ Congress's interpretation of copyrights, with the CTEA, ${ }^{268}$ and the courts' interpretations of copyrights,

262 See Metro-Goldwyn-Mayer Studios Inc. v. Grokster, Ltd., 125 S. Ct. 2764, 2772 (2005) (noting that the respondent marketed a product with the intent to profit from the infringement of others and encouraged such infringement).

263 See, e.g., Napster, 239 F.3d at 1013, 1019, 1022 (addressing arguments for direct, contributory and vicarious liability); Grokster, 125 S. Ct. at 2776 (2005) (addressing arguments for contributory and vicarious liability but ultimately holding respondent liable under a theory of inducement liability).

264 See generally 17 U.S.C. $\$ 501$ (2000).

265 See discussion infra Part III(a).

266 See Dallon, supra note 2, at 367-68.

267 The "public benefit" rationale and its history in copyright is discussed in detail in Part III(a) of this comment.

268 See S. Rep. No. 104-315 at 3 (listing "fairness to the artist" as a factor in passing the CTEA). 
in Eldred ${ }^{269}$ Napster $^{270}$ and Aimster, ${ }^{271}$ suggest that the courts, while they do mention the public benefit rationale, have acted mainly to protect the rights of the copyright holders, often at the expense of the public and without proof that the protection incentivizes creation. Courts have tried to strike a balance between copyright holders' benefits, the artists' incentives and the public domain, but the axis of this balance is in the wrong place.

1. Balancing artist's incentive with the public benefit

A discussion of a proper balance between artists' rights and the public benefit should start by recognizing two extremes. The public would achieve the maximum benefit from an artists' work if it had completely unhindered "productive" and "reproductive" use of it. Of course, the copyright clause, the Statute of Anne, and the printers licenses before it have underscored the point that the "maximum public benefit" is not achievable because artists would have no "incentive" to create new works. ${ }^{272}$ On the other side of the pendulum, the "maximum artists' benefit" would be achieved through perpetual copyright. History, however, explicitly rejects this conclusion in favor of the public benefit rationale. ${ }^{2 / 3}$ It is clear that a balance is necessary, but that balance should be focused from a de minimis perspective in terms of copyright, and should take into account a number of factors, including the realities of how the "method" of monetary incentives relates to artists' decisions to create works in a given industry.

The doctrine of "fair use" has historically been the judiciary's method of guarding against the harshness of copyright statutes, but this doctrine should be broadened to ensure that the Copyright Act meets the underlying "purpose" of the Copyright Clause. In other words, the judiciary, in an effort to ensure that Congress has not overstepped the limitations provided under the Copyright Clause, should engage in a "public benefit" assessment of Congressional legislation and determine the minimum amount of copy protection necessary in order to maintain an incentive for artists to create new works. This judicial

269 See Eldred v. Ashcroft, 537 U.S. 186, 199, 204 (2003) (accepting, under rational review, Congress' extension of the protection provided by the Copyright Act by 20 years).

270 See generally A\&M Records, Inc. v. Napster, Inc., 239 F.3d 1004 (9th Cir. 2001) (ignoring the premise that the public benefits merely from having access to music online).

271 See generally In re Aimster Copyright Litig., 334 F.3d 643 (7th Cir. 2003) (ignoring the premise that the public benefits merely from having access to all of this music online).

272 There is, of course, the Jewish law-based argument that attribution and accurate copying are protection enough because writers and artists have reasons besides monetary incentive to create expressive works. This argument has also been addressed in an Internet context. See generally Litman, supra note 16, at 24-25.

273 This concept is addressed in detail in Part III(a) of this comment. 
balancing would necessitate an "in-between" standard for noncommercial use, where there is no commercial piracy and the "potential market effect" is only judged by the aggregate effects of copying copyrighted material.

This is not to say that artists should receive only a minimum of protection. From an "artists' benefit" perspective, the core of copyright law should be focused on the prevention of profitable uses. Copyright owners should definitely be allowed to prevent others from making a profit off of their work, but where the question of profit is in the aggregate only, the court should consider additional factors in its fair use analysis beyond the traditional four factors mandated by the 1976 act. $^{274}$ Courts (and legislatures) should examine (1) the incentive provided to the author by his industry and whether the author's primary incentive in the creation of the works in question is monetary, (2) how long, on average, that monetary incentive lasts, ${ }^{276}$ (3) whether a given restriction on copyrighted material displaces other uses of a technology that may ultimately be "fair," and (4) whether the benefit provided to the public by the availability and enjoyment of expressive works displaces potential loss in artists' incentives. If "public benefit" is the central concern, what is the point of limiting access to an artists' work when the artist is not making money from it and the limitation imposes restrictions that infringe on legitimate uses?

\section{Balancing $\mathrm{P} 2 \mathrm{P}$ file sharing}

Applying this rationale in a $\mathrm{P} 2 \mathrm{P}$ context demonstrates two things: first, there are already a number of "fair" or "arguably fair" uses for P2P technology. These programs can be used to download public domain material as easily as they can be used to download copyrighted

27417 U.S.C. $\$ 107$ (2000).

275 If it can be shown that, on average, artists receive no money (or very little) from the publication of their works, where does this leave the rationale of the artists' incentive? If artists are creating works for free, and the public would be most benefited by access to those works, why impose restrictions on them at all? Placing these limitations on use makes sense when it is necessary to protect copyright holders who are engaging in dissemination, but if technology serves the dissemination function, we should be willing to reevaluate copyright incentives that have been based on the necessity of remunerating publishers.

276 This would essentially be a reason for a reduction of the terms of copyright protection rather than an extension of fair use, although one could argue that the fact that a work is past its moneymaking prime could enhance an argument for noncommercial fair use. Furthermore, record companies routinely stop printing albums after sales drop below a given level, which is usually after a few years. Singer-songwriter Janis Ian states flatly that she is "annoyed that so many records I once owned are out of print, and the only place I could find them was Napster." Ian Article, supra note 95. 
material. ${ }^{277}$ The Supreme Court has ratified "time shifting" as a fair use, arguably, those listening to songs they already heard on the radio are merely "time-shifting" those materials on their own. The argument that the listeners are getting commercial-free, deejay-free versions of those recordings is irrelevant, since the same could be accomplished by the studious use of a cassette player or CD-recorder.

There are other "arguably fair" uses of P2P networks which include "space-shifting," "sampling," and "library-building" that could be considered fair, but this is not really the point, because it confers no direct financial benefit to its users, noncommercial trading should fall into that "in between" category where it is necessary for the court to look at how private file sharing is affecting the author's incentive to create and the invention and use of new technologies.

This balance first necessitates a examination of the music industry as a whole in order to answer the first two "factors": (1) the incentive provided to the author by his industry and whether the author's primary incentive in the creation of the works in question is monetary and (2) how long, on average, that monetary incentive lasts.

If artists made CDs in order to make money in the music industry, they would be very poor. The average professional artist-after production, distribution, and promotion costs-actually loses money on his CDs. ${ }^{278}$ Most artists make most of their money from playing in live shows and, in some cases, merchandising, but only artists at the very top of the industry ever see any money from the sale of their CDs. Therefore, it would be fair to say that even if artists got into the "music business" to make money, the primary benefactor of CD profits is the middleman, the record label. This is similar to the "printer's licenses" in medieval Europe, which were set in place specifically to ensure that publishers would recoup their costs for production and distribution without fear that their market would be diluted by for-

277 By themselves, $\mathrm{P} 2 \mathrm{P}$ programs are simply file searching and transferring mechanisms that do not discriminate between file types. See discussion infra Part II(a).

278 See Albini, supra note 188. Steve Albini, a record industry insider, breaks down the cash amounts involved in an average recording contract and how those amounts are generally stacked against artists. Albini notes that after making the first album in a four album contract and accounting for all of the industry-standard deductions, his hypothetical major label band:

is now $1 / 4$ of the way through its contract, has made the music industry more than 3 million dollars richer, but is in the hole $\$ 14,000$ on royalties. The band members have each earned about $1 / 3$ as much as they would working at a $7-11$, but they got to ride in a tour bus for a month. The next album will be about the same, except that the record company will insist they spend more time and money on it. Since the previous one never "recouped," the band will have no leverage, and will oblige. 
profit pirates. The costs incurred in the production of music, however, have decreased dramatically with the advent of digital technology. ${ }^{279}$ It simply does not cost as much today to make a song or a record as it did 10 years ago, and to the extent that record companies say it costs the same or more, they are simply being wasteful. Furthermore, the costs that are incurred in distributing music are precisely the same costs that are (or should be) significantly reduced by the Internet. It is simply no longer necessary to press hundreds of thousands of CDs and ship them across the United States because posting them on a single website with enough bandwidth accomplishes precisely the same end. Record companies should not ask, via copyright infringement suits in the courts, for the public to subsidize an outmoded method of production and distribution.

The average life of a song, in terms of being a viable candidate for printing and distribution, is much shorter than its viability for taking up not-very-much space on several thousand hard drives in a P2P network. ${ }^{280}$ Certainly, there are songs that have a long "shelf-life" and are worth printing and shipping again and again, but these are the exception, not the rule. Examining copyright from a public benefit perspective should give us pause in saying that the rule should be written from the perspective of the exception. If we acknowledge that a large number of the songs available on P2P networks have outlived their "profitable lives," and we acknowledge that the public would benefit from access to those songs, and we assume that those songs are not being used to make a profit for someone other than the author, there is no incentive to curtail their private use and enjoyment by members of the public.

The third aspect of the "in-between" balancing test asks us to examine the nature of P2P file-sharing services themselves and ask whether a restriction on the use of that software would undermine the public benefit of the copyright clause by placing restrictions on the "fair use" of other works already in the public domain. The balance of this factor clearly lies in favor of the P2P networks, since, in addition to the other arguments posed above, curtailing infringing activity on

\footnotetext{
279 The wide availability and high quality of digital recording equipment has significantly decreased the fixed costs of producing music. Expensive reel-to-reel machines that were ubiquitous 30 years ago are now only in vogue for artists seeking a "vintage" sound.

280 For a very interesting viewpoint on consumer behavior with the Internet as a vehicle for finding and disseminating works, see Chris Anderson, The Long Tail, WIRED MAG. (October 2004), available at http://www.wired.com/wired/archive/12.10/tail.html. Anderson posits that the future lies in Internet technology's ability to address cultural niches, because the Internet, with its ability to store information cheaply and indefinitely and its ability to reach out to consumers all over the world, can make potentially valuable markets by aggregating a world full of users with common interests. See id.
} 
these networks would necessarily curtail the public benefit provided by the availability of these file-sharing programs in the first place. The public's access to works in the public domain should be the chief consideration, and since P2P file sharing improves access to these works, it should not be curtailed. This is consistent with the Supreme Court's "fair use" rationale in Williams \& Wilkins and in Sony.

The fourth aspect of the "in-between" balancing test is simple balance, does the benefit provided to the public by the availability and enjoyment of these works displace the artists' incentives to create new works? Since artists receive very little money for the writing and production of their CDs, it is hard to argue that allowing P2P file sharing will impact the amount an artist can make on a CD, and therefore impact their financial incentive to create new works. It will impact the middlemen, the record labels, who are making the lion's share of the profit from CD sales. Under the old copyright regime of the 1976 act, this would have been disastrous because an artist's only route to the public was via a well-financed music publishing and distributing entity, but this is simply no longer true. It is important to keep in mind, however, that this new standard does not affect an artists' right to make all profit from the sale of his material, it merely suggests that where the material is being consumed and shared in a noncommercial sense, not sold, the standards should be different.

\section{CONCLUSION}

File sharing, whether we like it or not, is here to stay. Regardless of whether any of the arguments above are compelling, this technology is a reality that we are going to have to start dealing with sooner or later. Record companies may not be able to "compete with free," and in spite of the Supreme Court's ruling holding Grokster liable, file sharing probably cannot be stopped because the program architecture is entirely decentralized. ${ }^{281}$

But where does the law sit? Recognizing that file sharing is here to stay and saying it is legal are two different things. History, however, supports a vision of copyright law that is grounded in prohibiting commercial infringement, and seems to have been designed for a physical distribution system that is currently an outmoded means of production. Furthermore, copyright is a statutory monopoly, and like other monopolies, we should approach copyright from a perspective that applies the minimum amount of protection necessary to accomplish its purpose, incentivizing the creation of expressive content. If

281 At the time this conclusion was written, on Saturday, February 4th, 2006, there were 2,611,175 users on the now-illegal FastTrack network sharing 273,066,117 files with one another. 
the current state of the recording industry makes it clear that artists create not with the hope of financial remuneration but with the hope of increasing their exposure to audiences worldwide, then our understanding of copyright as a potentially repressive monopoly would require us to restrict the protection. In other words, if artists will create music recordings for free, then we should not impose a monopoly that makes the public pay for musc.

With that premise in mind, we then need to consider whether the law affords our legal system a vehicle for this emerging jurisprudence. The fair use doctrine would be an excellent way for courts to reinstate an understanding of copyright law based on the concerns described above. Under section 107 of the Copyright Act, courts are allowed to take other factors into consideration besides the four factors listed in the act itself. ${ }^{282}$ A public interest based version of copyright jurisprudence should prompt courts to examine (1) the incentive provided to the author by his industry and whether the author's primary incentive in the creation of the works in question is monetary, (2) how long, on average, that monetary incentive lasts, (3) whether a given restriction on copyrighted material displaces other uses of a technology that may ultimately be "fair," and (4) whether the benefit provided to the public by the availability and enjoyment of expressive works displaces potential loss in artists' incentives. Applying this rationale to P2P file sharing makes it clear that this use could easily be considered fair, at least under circumstances where the end-user is not making a profit from an artist's copyrighted work.

This article is simply attempt to match the law to what appears to be an emerging economic reality. The public is unlikely to support a law that holds a large number of Americans liable to major record conglomerates because they downloaded the new Beastie Boys song they just heard on the radio. In fact, history lends support an alternate understanding of what copyright is designed to do, and, as with the photocopier and the VCR, we should endorse a vision of copyright that balances the public's expectations with the incentives of artists.

282 See 17 U.S.C. $\$ 107$ (2000). 